Revista Iberoamericana. $\quad$ Vol. LXII, Núm. 175, Abril-Junio 1996; 545-575

\title{
UN POETA PERUANO CONTEMPORÁNEO: BELLI ENSAYO BIBLIOGRÁFICO (1958-1995)
}

\author{
POR \\ Olga EsPejo \\ University of Miami
}

Desde hace muchos años la poesía de Carlos Germán Belli (1927), ocupa no sólo un lugar muy importante en la literatura peruana sino que ha recibido también reconocimiento internacional. El presente trabajo abarca toda la obra literaria de Belli, desde 1958, fecha de publicación de su primer libro, así como el material escrito sobre la misma hasta 1995.

Con la aparición de Poemas, publicado en 1958, Belli introdujo una poesía nueva, un estilo en el cual se mezcla lo tradicional y lo moderno; la dicción y metros de la poesía española de laEdad de Oro con un lenguaje moderno y coloquial. Belli expresa su realidad y la sociedad en que vive utilizando temas de frustración, angustia, fracaso y alienación. Sebastián Salazar Bondy, "Un poeta y el compromiso que asume", encuentra poemas excelentes y creativos en Poemas, sin embargo, encuentra también en este libro, poemas superficiales y faltos de espontaneidad; mientras que Víctor Ernesto Pool, "Un reciente poemario de Carlos Germán Belli", estima que Belli a veces improvisa y otras veces se adhiere a estrictas reglas no siguiendo, de este modo, fórmulas definitivas.

Dentro \& fuera, publicado en 1960, motivó a José Miguel Oviedo, "El cuerpo del surrealista: Belli", a animar a Belli a abandonar estilos antiguos y caducas influencias surrealistas que por estar fuera de moda no despertaban el antiguo interés. Oviedo señala, sin embargo, tres excelentes poemas en este libro que demuestran la habilidad del poeta en el uso del lenguaje y las experiencias interesantes que tiene que revelar y compartir. Esto, piensa Oviedo, debería estimular a Belli a seguir escribiendo. Carlos Cortínez, "Dentro \& fuera de Carlos Germán Belli” en Poesia latinoamericana contemporánea: (Borges, Neruda, Vallejo, Huidobro, Rojas, Belli, Rubio, Hahn), analiza los poemas de Dentro \& fuera.

La publicación de !Oh Hada Cibernética! produjo una reacción muy favorable de los críticos. Abelardo Oquendo, "Belli, una poesía desgarrada", encuentra una serie de contrastes en esta obra, tal como la combinación del lenguaje arcaizante con temas contemporáneos y una visión negativa de la vida mientras conserva la esperanza de seguir viviendo. Estuardo Núñez, La literatura peruana enel siglo XX: 1900-1965, sitúa a!Oh Hada Cibernética! entre la mejor y más destacada poesía peruana. El lenguaje, la mezcla de emoción intensa e ironía son manejadas hábilmente. Luis Loayza lo considera un libro escrito cuidadosamente, que demuestra que el poeta tiene gran preocupación por la forma al mismo tiempo que expresa una visión realista del mundo. En "La poesía de Carlos Germán Belli”, Loayza señala: "Su poesía no es sólo una bella construcción verbal, sino la expresión profunda de una vida y un testimonio lacerante sobre nuestra sociedad". 
El pie sobre el cuello, 1964, también produjo reacción de la crítica que se concentró principalmente en el uso de los temas y del lenguaje que emplea. Gordon Brotherston, "Modern priorities," escribe: "The deterioration of the world he inhabits is, then, that of the language he describes in it. So, that, within his poems, the intimation of recovered stature, of 'perennial ardent love,' has definite historical and political overtones." James Higgins en "The poetry of Carlos Germán Belli," hace un anális a fondo de esta obra y encuentra que: "His poetry revolves obsessively around the same basic situations, for this is a man trapped in an intolerable predicament from which he cannot break free." Manuel Lerín en su reseña "Poesía de Belli" comenta: "Esta poesía no puede perderse de vista, su hondura, su trazo poco comunes, son válidos y elogiosos". José Miguel Oviedo, "Belli: magia y exasperación", a su vez, encuentra que Belli ha abandonado la influencia vanguardista y se ha convertido en uno de los mejores, más originales e importantes poetas peruanos desde Martín Adán.

De acuerdo a Julio Ortega, "Calidad expresionista de Belli", Por el monte abajo, 1966, confirma y refuerza el lugar de Belli como el mejor poeta peruano de su tiempo. Ortega comenta sobre el uso del lenguaje y la visión de la realidad y sitúa la poesía de Belli entre la mejor de América Latina; y José Miguel Oviedo, "Belli: otra inmersión en el mismo infierno", considera que con este libro el poeta confirma, nuevamente, su lugar entre los más originales y profundos poetas de la América Española.

Sextinas y otros poemas, 1970, provocó reseñas variadas. José Miguel Ibañez Langlois, "Belli: Sextinas y otros poemas", considera que el estilo de Belli seguramente tendrá pocos seguidores, sin embargo, lo encuentra eficaz y de gran calidad y fuerza reveladora; mientras que Abelardo Oquendo, "Belli: una coyuntura difícil", encuentra que con este trabajo el poeta ha agotado los temas y debe de encontrar otro enfoque a su poesía.

Carlos Meneses reseña Asir la forma que se va, 1979, diciendo que a pesar de que los temas de Belli siguen siendo los mismos, su poesía es siempre nueva. Meneses considera que Belli está entre los poetas más leídos de la América Española.

A Canciones y otros poemas, 1982, le siguió la publicación de Boda de la plumay la letra en 1985. Belli continúa escribiendo en el mismo estilo y utilizando los mismos temas y su obra continúa siendo elogiada. Javier Sologuren, "Belli selecto: Boda de la pluma y la letra", afirma: "Belli es poeta de una sola, honda y dramática experiencia moral: la injusticia que acosa al hombre tornándolo en un ser condenado a perpetua frustración".

En 1986, Belli publica El buen mudar y Más que señora humana. Estas obras son seguidas por Antología personal, 1988, y en el mismo año En el restante tiempo terrenal y Antología crítica, compilada y anotada por John Garganigo. Acerca de este penúltimo libro Marco Martos, "Un poeta revisa a otro poeta: Belli y el paraíso terrenal", evalúa la poesía de Belli ocupándose principalmente del uso del lenguaje, y concluye: "Vivir el paraíso terrenal aquí y ahora es la divisa novísima de la poesía belliana. Doy curso a mi libérrimo sueño e imagino al antiguo amanuense abrazando a una muchacha. Amén".

A estas obras le siguió en 1990: Bajo el sol de la media noche rojo, que anteriormente fue publicada bajo el título de Más que señora humana y en 1992 Belli publicó: Acción de gracias y Los talleres del tiempo: poemas escogidos editado por Paul W. Borgeson Jr.

A través de su carrera literaria Belli ha recibido varios premios, becas y reconocimientos. En 1962, recibió el Premio Nacional de Poesía (Perú) por !Oh Hada Cibernética!; ha recibido también el prestigioso Guggenheim Foundation Fellowship y participado en el International 
Writers Workshop en 1969 y 1977, en la Universidad de Iowa; en 1982, fue electo a la Academia Peruana de la Lengua; y en 1986, recibió el Premio de Fomento a la Cultura otorgado por la Sociedad de Industrias (Perú), en reconocimiento a su contribución a las letras peruanas. En 1990 Belli fue invitado a participar en la Miami Book Fair International donde presentó varios de sus poemas.

Los poemas de Belli también han sido publicados en periódicos y revistas y traducidos a otros idiomas. O Fata Cibernetica! la traducción al italiano de !Oh Hada Cibernética! fue publicado en 1983 y Un giorno l'amore en 1995 basado en parte en !Oh Hada Cibernética! Su trabajo ha sido evaluado y elogiado por escritores y críticos literarios como W. Nick Hill quien ha estudiado a fondo la obra de Belli. En Tradicióny modernidad en la poesia de Carlos Germán Belli, Hill hace un análisis detallado de la misma. El libro consiste de una introducción, tres capítulos y conclusión. La introducción cubre los antecedentes de la poesía hispanoamericanay la forma en que Belli encaja y se desarrolla en ella. El primer capítulo trata de los principios literarios de Belli, sobretodo de su dos primeros libros de poesía. En el segundo capítulo hace un estudio de !Oh Hada Cibernética!, El pie sobre el cuello y Por el monte abajo. El capítulo final se concentra principalmente en las obras: En alabanza del bolo alimenticio y Sextinas y otros poemas. Hill hace un examen exhaustivo del lenguaje, temas, y contexto de la obra de Belli, y como lo indica el título, el autor demuestra cómo estos dos contrastes, lo moderno y lo tradicional, se funden en la obra belliana.

John F. Garganigo en el prólogo a Antología crítica proporciona una importante evaluación de la obra de Belli. El autor señala algunas similitudes con escritores como Góngora, Vallejo, Quevedo y otros más. Garganigo considera la poesía de Belli creativa y original.

Otro importante crítico de Belli es James Higgins quien ha escrito varios estudios sobre su obra. Uno de ellos es "Carlos Germán Belli" en The Poet in Peru: Alienation and Quest for a Super-reality. En este estudio Higgins examina el lenguaje, temas e imágenes de varios de los poemas. La manera original en que el poeta combina el lenguaje clásico con expresiones coloquiales y temas e imágenes contemporáneas. Algunos de los temas que resaltan en la obra son frustración, alienación, derrota, y lucha constante.

En 1967 Leonidas Cevallos, "Sobre la poesía de Belli", resaltó que en su consideración Belli es el poeta más creativo desde César Vallejo; y Enrique Lihn, "Carlos Germán Belli", señala: "Perhaps the most eccentric poetic language to arise in the last twenty-five years. And also, perhaps, the one most deeply anchored as a thorn in the flesh in the fundamental problems of Latin America, where all of us live and write 'with a foot on our throat'".

Javier Sologuren, poeta peruano y crítico literario, ha escrito también varios artículos sobre Belli. Ha estudiado los temas, influencias, lenguaje, imágenes y otros aspectos de la poesía de Belli y en 1986 escribe: "Belli es a la par antípoda y parangón del creador de Trilce".

Otro crítico peruano, Jorge Cornejo Polar, ha seguido también la trayectoria de Belli y publicado varios artículos sobre su obra. En 1994 publicó: Lapoesía de Carlos Germán Belli: una aproximación.

Finalmente, en Hispanic writers: a selection of sketches from contemporary authors, editado por Ryan Bryan, encontramos que: "Carlos Germán Belli has been called one of the most original Hispanic poets writing today [...] his poems use irony and black humor to comment bitterly on the social injustices in his native Peru brought about by bureaucracy and 
technology. However, he also extrapolates this outrage to address his nihilistic view of mankind's destiny as a whole. More recently, his poetry has assumed a metaphysical tone".

Durante varios años Belli dictó clases en la Universidad Nacional Mayor de San Marcos y hasta la fecha colabora en el diario El comercio de Lima.

Los trabajos arriba citados están incluídos en la bibliografía.

Obras de BeLli (1958-1994)

Poemas. Lima: [El Autor, impreso en Talleres Gráficos Villanueva], 1958.

Dentro \& fuera. Lima: Escuela Nacional de Bellas Artes, 1960.

!Oh Hada Cibernética! Lima: El Timonel, 1961.

!Oh Hada Cibernética! Lima: La Rama Florida, 1962. ( $2^{\mathrm{a}}$ ed. aumentada).

El pie sobre el cuello. Lima: La Rama Florida, 1964.

Por el monte abajo. Lima: La Rama Florida, 1966.

El pie sobre el cuello. Montevideo: Alfa, 1967. (incluye previas publicaciones).

Sextinas y otros poemas. Santiago de Chile: Editorial Universitaria, 1970.

!Oh Hada Cibernética. Caracas: Monte Ávila, 1971. (antología que incluye El libro de los nones).

En alabanza del bolo alimenticio. México, D.F.: Premiá, 1979. (incluye El libro de los nones).

Asir la forma que se va. Lima: Cuadernos de Hipocampo, 1979. (breve antología).

Canciones y otros poemas. México, D.F.: Premiá, 1982.

Boda de la pluma y la letra. Madrid: Ediciones Cultura Hispánica, Instituto de Cooperación Iberoamericana, 1985.

El buen mudar. Madrid: Ediciones del Tapir, 1986. (poemas).

Más que señora humana. Lima: Editorial Perla, 1986.

El buen mudar. Lima: Editorial Perla, 1987 (prosa y poemas).

Antología personal. (Jorge Cornejo Polar, ed.) Lima: CONCYTEC, 1988.

Antología crítica. (Selección y notas de John Garganigo). Hanover, N.H.: Ediciones del Norte, 1988.

En el restante tiempo terrenal. Lima: Editorial Perla, 1988.

Bajoel sol de la media noche rojo. México, D.F.: Premiá, 1990. (Publicado previamente bajo el título: Más que señora humana).

En el restante tiempo terrenal. Lima: Desa, 1990. (3 ${ }^{\text {a }}$ ed. ampliada).

Acción de gracias. Trujillo, Perú: Municipalidad Provincial de Trujillo, Casa del Artista, 1992.

Canciones y otros poemas. Trujillo, Perú: Ediciones SEA: Municipalidad Provincial de Trujillo, Casa del Artista, 1992.

Los talleres del tiempo: poemas escogidos. (Paul W. Borgeson Jr., ed.) Madrid: Visor, 1992.

TRADUCCIONES

O Fata Cibernetica! (Introducción y selección de Roberto Paoli y Carlotta Nerozzi). Reggio Emilia: Elitropia Edizioni, 1983. Un giorno l'amore. (Traducción de Roberto Paoli y Martha Canfield). Milano: Edizioni Olivares, 1995. 


\section{Grabaciones}

Peruvian Poet Carlos Germán Belli Reading from His Work. 1977. Cinta grabada el 21 de diciembre de 1977, en la Library of Congress Recording Laboratory, Washington, D.C., para el Archive of Hispanic Literature on Tape.

Poetry Reading. Cambridge, Mass.: Woodberry Poetry Room, 1984. Cinta grabada en 1984. Se encuentra en el Woodberry Poetry Room, Harvard University Library.

Poetry Reading. Introduced by Professor Kristal. Cambridge, Mass.: Woodberry Poetry Room, 1988. Cinta grabada en 1988. Se encuentra en el Woodberry Poetry Room, Harvard University Library.

\section{Poemas de Belli en Antologias y Revistas}

Ahern, Maureen and David Tipton, eds. Peru, the New Poetry. London: Magazine Editions, 1970. 34-39. Incluye: "Segregation", "10 poems from 'O Hada Cibernetica " y "Tongue-tied". Traducción al inglés de Maureen Ahern.

Baciu, Stefan, selección, prefacio, introducción y anotaciones. Antología de la poesía latinoamericana, 1950-1970. Albany: State University of New York Press, 1974. vol. 2(1000-1006). Unabreve introducción sobre CGB seguidade "Los engranajes", “Abajo las lonjas", "Sextinas de los desiguales" y "Segregación no. 1".

Barros, Daniel, ed. Antología básica contemporánea de la poesía latinoamericana. Buenos Aires: Ediciones de la Flor, 1979. 209-11. Comprende representantes de veinte países. Incluye tres poemas de CGB: "Poemas", "El olvidadizo" y "El moho".

Boccanegra, Jorge, Saúl Ibargoyen, [eds.]. Poesía contemporánea de América Latina. $1^{\mathrm{a}}$ ed. México: Editores Mexicanos Unidos, 1982. 203-204. Están representados escritores de veintitrés países. Incluye: "Sextina de los desiguales".

Bonilla Amado, José, selección y notas. Antología de la poesía peruana. Lima: Libertadores de América, [1984]. 129-31. Antología de setenta y cinco poetas. Incluye: "Segregación n 1", "Ha llegado el domingo" y "!Oh Hada Cibernética!".

Bravo, José Antonio, [ed.]. La Generación del '50: hombres de letras. $1^{\text {a }}$ ed. Lima: Universidad Nacional Mayor de San Marcos, Instituto Raúl Porras Barrenechea; Okura Editores, 1989. 1-2. Incluye un ensayo bio-bibliográfico y el poema "El atarantado".

Cáceres Urrutia, José, prólogo, selección y notas. Antologia de la poesía peruana. Lima: Ediciones Centauro, [1986?]. 52. Incluye: "Poema" y "Papá, mamá".

Caracciolo-Trejo, E., ed. The Penguin Book of Latin American Verse. England: Penguin, 1971. xxvi, 344-45. Incluye: "En vez de humanos dulces", "Poema" y "!Oh Hada Cibernética!". Poemas en español e inglés.

Cobo Borda, Juan Gustavo, selección, prólogo y notas. Antología de la poesía hispanoamericana. México: Fondo de Cultura Económica, 1985. 348-53. Incluye seis poemas de CGB: "Amanuense", "El atarantado", "Ni de cien mil humanos", "Poema", "Sextina de los desiguales" y "Canción en alabanza del bolo alimenticio y en reprimenda del alma".

Donoso, José and William A. Henkin, eds. The Tri-Quarterly Anthology of Contemporary Latin American Literature. 1st. ed. New York: Dutton, 1969. 186-93. Incluye: "20 poems from $O$ Hada Cibernetica!'. Poemas traducidos por Clayton Eshleman. 
Donoso Pareja, Miguel, selección y prólogo. Poesía rebelde de América. México: Editorial Extemporáneos, 1971. 333. Comprende representantes de veinticuatro países. Incluye: "Poema". (Este poema bajo el título "Papá, mamá" fue incluído en El pie sobre el cuello. Montevideo: Alfa, 1967. 48.

Duran, Cheli, ed. and trans. The Yellow Canary Whose Eye Is So Black. New York: Macmillan, 1977. 298-301. Incluye: "En vez de humanos dulces" y "Papá, mamá". Poemas en español e inglés en páginas opuestas.

Escobar, Alberto, prólogo, selección y notas. Antología de la poesía peruana. Lima: Nuevo Mundo, 1965. 176-81. Incluye una introducción breve sobre CGB seguida de diez poemas: "Poema", "Poema", "Segregación n 1", "Te cuelas a través de uno de los postigos", "Ha llegado el domingo", "Mi cuerpo extiende su busto durante la noche", "!Oh Hada Cibernética!", "Oh alma mía empedrada", "Papá, mamá" y "Oh padres sabedlo bien".

prólogo, selección y notas. Antología de la poesía peruana. Lima. Ediciones Peisa, 1973. vol. 1 (159-66). Incluye una introducción y breve bibliografía sobre CGB seguida deochopoemas: "Poema","Poema","!OhHadaCibernética!", "Losbofes", “Amanuense” "El atarantado", "Sextina de los desiguales" y "La cara de mis hijas".

García Rodríguez, Alfonso [y] Angel García Aller, comps. Antología de poetas hispanoamericanos contemporáneos. León: Nebrija, 1980. 269-72. Incluye una breve introducción sobre CGB seguida de seis poemas: "Nuestro amor", "Él avisó las señales", "Poema", "Amanuense", "Sextina de los desiguales" y "La cara de mis hijas".

Golpe de dados (Bogotá) 130 (jul-ago 1994): 63-80. Incluye: "Cuando Tirsis entra por un oído y sale por el otro", "El corazón hambriento", "El ambar" y "El hablante contento".

González Vigil, Ricardo, prólogo, selección y notas. Poesía peruana: antología general vol.

3, De Vallejo a nuestros días. Lima: Ediciones Edubanco, 1984. 171-75, 492-95. Incluye una bibliografia de CGB y los poemas: "Poema", "Papá, mamá", "Amanuense" y "Cuando el espíritu habla por la boca".

Haravi (Lima) 93 (jul 1994). Incluye: "Cuando Marcio entra por un oído y sale por el otro". Holzcán, Carlos Guillermo, selección y notas. Antología de la poesía erótica. Buenos Aires: Ediciones Globo Rojo, [1967]. 28. Incluye "Nuestro amor".

Jiménez, Reynaldo, selección. El libro de unos sonidos: catorce poetas del Perú. Buenos Aires: Ediciones Ultimo Reino, 1988. 59-76. Incluye una bibliografia de la obra de CGB y catorce poemas: "Poema", "Los contenidos", "Expansión sonora biliar", "!Oh alimenticio bolo!", "Papá, mamá", "Yo en nada ya me fio", "El hi del aire”, "Plexiglás", "La tortilla", "Canción primera", "Usted, bocaza", "Poema", "Canción en alabanza del bolo alimenticio y en reprimenda del alma" y "En el coto de la mente".

Lama, Víctor de, ed. Antología de la poesía amorosa española e hispanoamericana. Madrid: Edaf, 1993. 453-55. Cubre autores desde la Edad Media (siglos XI-XV) hasta el presente. CGB está incluido en el capítulo "Modernismo y nuevas promociones del siglo XX". Incluye los poemas: "Nuestro amor" y "A Filis".

Lastra, Pedro, selección e introducción. "Muestra de la poesía hispanoamericana actual". Hispamérica 4.11-12 (1975): 75-147. Comprende una introducción seguida de una antología de diez poetas que abarcan dos generaciones. Ocho poetas nacidos entre 19171930, y dos poetas, Oscar Hahn y José Emilio Pacheco, nacidos en 1938 y 1939 
respectivamente. Incluye también una bibliografia de cada uno de los poetas. Contiene doce poemas de CGB: "Poema", "Ha llegado el domingo", "Algún día el amor", "!Oh alma mía empedrada!”, "Papá, mamá”, “¡Oh padres, sabedlo bien!”, “!Cuánta existencia menos!", "!Oh Hada Cibernética”, "Cepo de Lima", "Sextina del mea culpa”, "Sextina de los desiguales" y "Donde empieza la gordura".

Lastra, Pedro [y] Luis Eyzaguirre, eds. "Catorce poetas hispanoamericanos de hoy." Inti 1819 (1983-1984): 131-46. Incluye "En alabanza de Carlos Germán Belli “ de Enrique Lihn (131-34); una nota bibliográfica (145-46); la introducción a Asir la forma que se va y diecinueve poemas de CGB: "Poema", "Segregación $\mathrm{n}^{\circ} 1$ ", "Las fórmulas mágicas", “Algún día el amor", "!Oh alma mía empedrada!”, "Papá, mamá”, "'Oh padres sabedlo bien!", "Ha llegado el domingo", "!Cuánta existencia menos!", "!Oh Hada Cibernética!”, “Amanuense", "Cepo de Lima", "Fisco", "Mis ajos", "El atarantado", "Sextina de los desiguales", "La cara de mis hijas", "Boda de la pluma y la letra" y "Villanela".

Lauer, M. y A. Oquendo, selección; introito de Antonio Cisneros. Poemas del amor erótico. Lima: Mosca Azul, 1972. 33-34. Antología de veinticinco poetas. Incluye: "A la noche" de CGB.

Luby, Barry J. and Wayne H. Finke, eds. Anthology of Contemporary Latin American Literature, 1960-1984. Rutherford, N.J.: Fairleigh Dickinson University Press; London: Cranbury, N.J.: Associated University Presses, 1986. 55-58. Incluye seis poemas: "Segregation $\mathrm{N}^{\circ}$ 1", "Someday Love", "Bah! Vitamin A", "Antibiotic Miscellany", "Sextain of Kid and Lulu" y "Looking at My Little Daughters, with Their Friend 'Daqui' the Dog". Traducción de Wayne H. Finke.

Molina, Alfonso, ed. Antología de la poesía revolucionaria del Perú. $3^{\text {a }}$ ed. Lima, Perú: Ediciones AméricaLatina, 1966. 90-91. Incluye: "Plexiglás", "La ración"y “Amanuense”. 9 Poetas peruanos: Bendezú, Belli, Washington Delgado, Carrillo, Corcuera, Tamayo Vargas, Sologuren, Cisneros. Facultad de Letras y Ciencias Humanas de la Universidad Nacional Mayor de San Marcos, Lima. [impreso en] Madrid: Maribel, Artes Gráficas, 1967. 30-37. Enumera las obras de CGB e incluye seis poemas: "!Oh Hada Cibernética! ya líbranos", "Plexiglás", "Poema”, “A mi hermano Alfonso", "Amanuense” y "Censo de la mala estrella".

Ortega, Julio, prólogo, selección y notas. Antología de la poesía hispanoamericana actual. México: Siglo Veintiuno Editores, 1987. 256-262. Incluye una breve introducción sobre CGB seguida de diez poemas: "Segregación n 1", "Poema", "Papá, mamá", “!Oh padres sabedlo bien!”, “!Oh Hada Cibernética!”, “Cepo de Lima”, "Robot sublunar”, "En el coto de la mente", "La cara de mis hijas" y "Sextina de los desiguales".

selección y prólogo. Imagen de la literatura peruana actual,1968. Lima: Editorial Universitaria, 1971. vol. 2 (1-3). Incluye: "Los estigmas", "Las cosas esquivas" y "Canción primera".

Oviedo, José Miguel [ed.]. "Poesía peruana de hoy." Sur 287 (mayo-abril 1964): 29-55. Consiste de una breve introducción, poemas de trece poetas y una nota breve sobre los mismos. Incluye: "Poema" de CGB.

Passalacqua, Rose. [selección y traducción]. Conjunctions 23 (1994): 111-14. Incluye un breve ensayo sobre la obra de Belli y el poema: "Variations for my brother Alfonso". 
Pellegrini, Aldo, ed. Antología de la poesía viva latinoamericana. Barcelona: Seix Barral, 1966. 243-47. Representantes de trece países. Incluye trece poemas de CGB: "Nuestro amor", "Te cuelas a través de uno de los postigos”, "!Oh Hada Cibernética!", “!Abajo las lonjas!", "Papá, mamá”, “Algún día el amor”, "Si aire sólo hay”, “!Oh alimenticio bolo", "Qué hago con este aposento", "!Oh padres sabedlo bien!", "Sea así: yo os confieso", "Los bofes" y "A mi hermano Alfonso".

Rodríguez Monegal, Emir, ed., with the assistance of Thomas Colchie. The Borzoi Anthology of Latin American Literature. New York,: Knopf, 1990. vol. 2 (824-30). Incluye una introducción sobre cada autor seguida de la traducción al inglés de un poema, selección de una novela o cuento. Incluye: "20 poems from O Hada Cibernetica!" traducidos por Clayton Eshleman.

Rodríguez Padrón, Jorge, selección y estudio preliminar. Antología de la poesía hispanoamericana, (1915-1980). Madrid: Espasa-Calpe, 1984. 246-60. Tiene una introducción sobre cada autor seguida de varios poemas. Incluye: "!Abajo las lonjas!”, "!Oh alimenticio bolo!”, "!Oh Hada Cibernética!”, "Sextina de los desiguales”, "!Oh alma mía empedrada!", “Cepo de Lima”, "En primavera”, "Donde empieza la gordura”, "Boda de la pluma y la letra", "Que muy pronto mañana", "Alimenticios bolos", "El aire, suelo y agua", "A Filis", "Cuando el espíritu no habla por la boca".

Ruano, Manuel, [ed.]. Muestra de la poesía nueva latinoamericana. Lima: El Gallinazo, 1981. 33. Incluye un poema de cada uno de los 146 poetas mencionados. CGB es representado por "Poema".

Saínz, Gustavo y Miguel Donoso Pareja, eds. Antología de la poesía erótica. México, D.F.: Editorial Orientación, 1972. 46. Incluye "Nuestro amor".

Salazar Bondy, Sebastián, selección. Mil años de poesía peruana. Lima: Populibros Peruanos, [1964?]. 131. Incluye "Las abolladuras".

San Marcos: revista de artes ciencias y humanidades (Lima) 19 (ene-dic 1978): 65-70. Incluye: "Que muy pronto mañana [...]", "Canción", "La rueda de la fortuna" y "El caníbal".

Silva-Santisteban, Ricardo, [ed.]. Antología general de la poesía peruana. Lima: Biblioteca Nacional del Perú, 1994. 583-91. La introducción es seguida de: "Poema”, “¿Por qué me han mudado?”, "El frío miedo [...]”, “!Cuánta existencia menos!”, “A mi hermano Alfonso", "Sextina primera", "A la noche", "A una tórtola” y “¿Cuándo señora mía [...]?".

Socialismo y participación (Lima) 72 (dic 1995): 101-107. Incluye "Uno propone pero no dispone" ensayo de Belli en el que expone cómo tuvo que tomar decisiones y cambiar de planes debido a causas externas y tres poemas: "Spes", "El destino de los escribas" y "El ambar".

Sucre, Guillermo, coordinador. Antología de la poesía hispano-americana moderna. $1^{\text {a }} \mathrm{ed}$. Caracas, Venezuela: Monte Ávila Latinoamericana, 1993. vol. 2(549-59). Incluye una breve introducción y bibliografía sobre CGB y los poemas: "Poema", "Segregación $\mathrm{n}^{\circ}$ 1", "Las fórmulas mágicas", "Menú", "Oh Hada Cibernética", "Si aire solo hay", "Oh alma mía empedrada", "Oh padres sabedlo bien", "En tanto que en su hórrido mortero", "Los bofes", “A mi hermano Alfonso", “La ración”," Amanuense”, "Poema”, “Misajos" $\mathrm{y}$ "Sextina de los desiguales". 
Tamayo Vargas, Augusto, ed. Nuevapoesíaperuana: antología. Barcelona: ElBardo, 1970. 35-44. En "Introducción: en elámbito de la antología (1949-1969)", el autor afirma que la poesía de Belli está influenciada por los clásicos, busca la formay es pesimista. La vida le proporciona dolor: "Tras su poesía de escape, hay una plena acentuación humana, pero insatisfacción, desesperanza y náusea." 21-24. Incluye un bosquejo bio-bibliográfico y diez poemas de CGB: "!Abajo las lonjas!”, "!Oh alimenticio bolo!”, "!Oh Hada Cibernética!", "Los bofes", "Robot sublunar", "Mis ajos", "Sextina del mea culpa", "Sextina de los desiguales", "Sextina de Kid y Lulú" y "Mirando a mis hijitas con su amigo, el can Daki".

Tipton, David, ed. Peru, the New Poetry. New York: Red Dust, 1977. 47-57. Antología de quince poetas. Incluye poemas de CGB traducidos al inglés: "Segregation", "Tonguetied" y 20 poemas de "O Hada Cibernetica!"

Toro Montalvo, César. Manual de literatura peruana. Lima: A.F.A. Editores, 1990. 653. Incluye una breve introducción seguida de: "Poema".

\section{CRÍtica E INTERPRETACIÓN SOBre BeLli}

Aguirre, Hugo. “Carlos Germán Belli presentó antología de su obra poética”. El comercio (Lima) 19 de junio 1986: C-13. Creador de bella poesía introspectiva siempre en busca de la palabra exacta. Influenciado por Darío, los modernistas, los clásicos españoles y la vanguardia, Belli, al mezclar todas estas influencias, hacreado un estilo propio. Escrito a raíz de la presentación de Boda de la pluma y la letra.

Anderson-Imbert, Enrique. Spanish-American Literature: a History. 2 vols. 2nd. ed. Rev. and updated by Elaine Malley. Trans. John V. Falconieri. Detroit: Wayne State University Press, 1969. vol. 2 (704). "Carlos Germán Belli, who toyed with pure forms in which there was a mixture of archaic voices and surrealist echoes, later produced, unforeseeably, poetry in which there were exasperated grimaces as well as humorous winks."

Baciu, Stefan. "Algunos poetas parasurrealistas latinoamericanos". Eco 228 (1980): 591601. El autor aplica el término parasurrealista al poeta que: "Sin ser explícitamente surrealista, coincide o ha coincidido - a veces-con el Movimiento o con su expresión poética". Los poetas peruanos mencionados son: J. Sologuren, Belli, y B. Varela.

Bazán, Dora. "Carlos Germán Belli y sus 'Sextinas”". Expreso(Lima) 25 de mayo 1971: 17. Analiza "Sextina de los desiguales".

Benedetti, Mario. "Carlos Germán Belli en el cepo metafísico". Letras del continente mestizo. $3^{\mathrm{a}}$ ed. ampliada. Montevideo: Arca, 1974. 182-86. Belli reconoce la injusticia del destino del hombre. Desdeña la vida, su existencia; usa hábilmente un lenguaje poético que es a veces barroco, rebelde, irónico y nihilista produciendo así, un efecto de tonos mágicos.

"En un pie de igualdad". América Latina en su literatura. César Fernández Moreno, ed. $3^{\mathrm{a}}$ ed. México, D.F.: Siglo Veintiuno, 1976. 355. Menciona brevemente a CGB reconociendo la influencia de Góngora en su poesía.

Bermúdez-Gallegos, Marta. Reseña de Antología crítica. Inti 34-35 (1991-1992): 287-88. A pesar de que los poemas seleccionados son válidos representantes de la obra de Belli y de que contiene una buena bibliografia, le falta a esta obra un estudio más profundo 
sobre las influencias y fuentes que inspiran al poeta a lograr este tipo de poesía. La preocupación de Belli por la forma poética, su sufrimiento y lucha espiritual, la forma que tiene de ver la realidad y los tonos políticos de alguno de sus poemas, hubiesen sido temas interesantes de tratar.

Borgeson, Paul W., Jr. "Introducción a la poética de Carlos Germán Belli". Plural 244 (enero 1992): 54-62. Elabora sobre el lenguaje, temas, símbolos e imágenes en la poesía de Belli: "Así, la de Belli es una obra unificada en todo sentido: preocupación constante por la forma, lenguage personal y cíclicamente recurrente y la línea temática que liga desde el primer poemario hasta el más reciente". Incluye los poemas: "Oh, Hada Cibernética", "Una desconocida voz", “A la zaga", "Amanuense”, "Contra el estío", "Cepo de Lima", "Autorretrato con apariencia humana", "Canción primera", "Boda de la pluma y la letra", "Villanela", "No salir jamás" y "El nido codiciado".

"El sistema simbológico de Carlos Germán Belli: expresión pública de un discurso privado". Los talleres del tiempo: poemas escogidos. Madrid: Visor, 1992. 9-20. Estudio que sirve como introducción del libro y presentación de la obra de Belli. El autor propone cinco categorías, o claves, para la interpretación y estudio de la simbología en la obra belliana. Publicado también en: El pesapalabras: Carlos Germán Belli ante la crítica. Miguel Angel Zapata, ed. Lima: Tabla de Poesía Actual, 1994. 65-77.

Brotherston, Gordon. "Modern Priorities". Latin American Poetry: Origins and Presence. Cambridge: New York: Cambridge University Press, 1975. 177-81. Se concentra en El Pie sobre el cuello. Utilizando la dicción de los escritores de la Edad de Oro, especialmente Garcilaso, y la métrica de poetas españoles del siglo diecisiete, como Góngora, Belli se presenta amargo, hostil y resignado. A pesar de ello, Belli no es fatalista pero sí un individuo fuerte, de intensas y definidas ideas políticas.

Cánepa, Mario. "Barroco y neobarroco: alienación en el mundo contemporáneo". Estudios de hispanismo contemporáneo: actas del primer Seminario Internacional Sobre 'Hispanismo en el Siglo XX'. Miguel Zugasti, ed. New Delhi: Embassy of Spain in New Delhi, 1990. 35-42. "El idealismo arcádico renacentista y la distorsión de la realidad que es el barroco, parecen solidarizarse en la poesía neobarroca belliana para aludir, con esa incoherencia de la expresión léxica, a la incoherencia y absurdo de un mundo real. Es la crisis del mundo actual y el medio anacrónico que conducen a la alienación. Ese 'injerto lingüístico' de cultismos, coloquialismos, peruanismos, vocablos insólitos, tecnicismos, aluden a esa incoherencia".

"Historia y máscara poética: sobre la poesía de C.G. Belli.” Lexis 12.1 (1988): 8390. Este análisis se concentra primeramente en el lenguaje y los temas. La realidad política y social de su país, la injusticia, opresión, humillación y burocracia son algunos de los temas recurrentes en la poesía de Belli, el cual los trata, a veces, con ironía y humor negro.

"Lenguaje en conflicto: la poesía de Carlos Germán Belli". Tesis de doctorado. City University of New York, 1985. 529 p. Demuestra la influencia del barroco y de los clásicos españoles, principalmente Garcilaso, Góngora, Quevedo y Medrano. La mezcla de elementos antiguos y modernos produce una poesía interesante y poco usual. La American Association of Teachers of Spanish and Portuguese, otorgó a Cánepa el Premio Huntington por la mejor disertación en la décima tercera Reunión Anual de Gala el 8 de marzo de 1986. 
Lenguaje en conflicto: la poesia de Carlos Germán Belli. Madrid: Orígenes, 1987. $240 \mathrm{p}$. Basado en el último capítulo de la tesis doctoral del autor. Incluye dos entrevistas. Fragmentos (1-41) en: El pesapalabras: Carlos Germán Belli ante la crítica. Miguel Angel Zapata, ed. Lima: Tabla de Poesía Actual, 1994. 119-39.

Cevallos Mesones, Leonidas. "Sobre la poesía de Belli". Mundo nuevo 8 (1967): 84-86. Considera a Belli el poeta más creativo desde César Vallejo. Reseña Poemas, Dentro \& fuera, El pie sobre el cuello, !Oh Hada Cibernética! y Por el monte abajo.

Cisneros, Antonio. Reseña de Por el monte abajo. Amaru 1 (1967): 89-92. A primera vista los poemas parecen ser complejos pero esta complejidad reside en el lenguaje y en los 'personajes' que utiliza tales como: Hada Cibernética, Fisco, Marcio, etc., pero la poesía de Belli no encierra un significado oculto. Los temas son simplemente repetidos en forma diferente: "Belli ha logrado imponernos su increíble universo, mas Por el monte abajo parece estar girando sobre sus propios límites y corre el peligro de desgastarse, pues habiendo creado una retórica personal de probada calidad, bien puede ser ganado por esa eficacia".

Clementelli, Elena. "Una raccolta di versi del peruviano Carlos Germán Belli: la Fata Cibernetica." Il Tempo giug. 7 1985: 23. Poesía interesante de influencia clásica y vocabulario moderno que utiliza armoniosas y disonantes yuxtaposiciones.

Cornejo Polar, Jorge. "Belli ante la crítica". El mundo(Lima) semana del 3 al 9 de julio 1994 [sección Artes \& letras]. Reseña de El pesapalabras: Carlos Germán Belli ante la crítica. Miguel Angel Zapata, ed. El autor encuentra que la selección de los textos ha sido muy acertada pues incluye estudios de críticos peruanos y extranjeros, así como estudios extensos y breves que representan diversas etapas de la obra literaria de Belli. Y concluye: "Puede afirmarse que a partir de ahora este recuento crítico se convierte en indispensable apoyo para todo aquel que quiera acercarse con seriedad a la obra extraordinaria de Carlos Germán Belli, el poeta".

"Belli: asir la forma que se va". La crónica, suplemento Hipocampo(Lima) 22 de junio 1986: 5. Reitera la importancia de Belli en la poesía peruana y considera que hay en él un conflicto interior y que existen en su poesía ciertas ideas muy arraigadas: amor y cariño; la búsqueda del conocimiento; y la habilidad y dominio de la práctica poética y la inspiración. Este artículo fue también publicado, con ligeras variantes, en El café literario (Bogotá) 48.9 (ene-mar 1987): 33-35.

"Belli, el petrarquista" El comercio (Lima) 21 de abril 1995: A3. Señala que parte de la influencia de Petrarca en CGB consiste en el tamaño de la estrofa y la extensión del verso y concluye: "Por esas cosas maravillosas que tiene la literatura, entre Francesco Petrarca (1304-1374) y su Canzoniere y Carlos Germán Belli (1927) y su obra, se tiende una línea de relación que explica que la "canzone" petrarquesca renazca transfigurada en nuestras letras. Todo el mérito de esta hazaña corresponde, claro, a Belli, el petrarquista". "Belli, nueva etapa". Página libre 8 de julio 1990: 18. Examinando los poemas de En el restante tiempo terrenal encuentra que: "Por el tono general de los nueve poemas que forman este volumen breve, pero rico en novedades, en varios de los cuales se habla de una nueva etapa que se inicia para el yo poético que la postula, además como distinta y mejor que la anterior". 
"Belli o la diferencia" El comercio suplemento dominical (Lima) 2 de julio 1993: 19. Considera la obra de Belli diferente e inconfundible y Los talleres del tiempo un libro formado de poemas acertadamente escogidos que reflejan una obra: "Nacida de la dolorosa conciencia de la persona poética de ser diferente por menoscabo, esta poesía muestra cada vez con mayor claridad su otra diferencia, esta vez por la excelencia a que ha llegado que la singulariza en el poblado panorama de la poesía hispanoamericana de fin de siglo". Este artículo más ampliado apareció en: El pesapalabras: Carlos Germán Belli ante la crítica. Miguel Angel Zapata, ed. Lima: Tabla de Poesía Actual, 1994. 21528.

"Lo deseable como categoría poética". Expreso 20 de mayo 1980. No fue examinado personalmente.

"Las musas de Eguren y Belli: de la 'Niña de la lámpara azul' al 'Hada Cibernética"' El peruano suplemento cultural Revista (Lima) 19 de diciembre 1994: 4-5. Estudio comparativo de la figura central en estos dos poemas en el que señala que no obstante el tiempo que separa la publicación de ellos - Eguren (1916) y Belli (1960) encuentra en los poetas "una marcada comunidad espiritual".

"La poesía de Carlos Germán Belli". Eco 18 de mayo 1969. No fue examinado personalmente.

La poesía de Carlos Germán Belli: una aproximación. Lima: Universidad de Lima, Facultad de Ciencias Humanas, 1994. Analiza la obra de CGB señalando las diferentes etapas de la creación belliana.

“La poesía última de Carlos Germán Belli”. La manzana mordida 13 (julio 1982): 3240. Artículo compuesto de las siguientes partes: Primera aproximación a un arte poética; El deseo y laalteridad; La comunicación por lo erótico; Dos poemas sobre el texto poético y Nota final sobre el deseo y lo deseable.

Cortínez, Carlos. "Dentro \& fuera de Carlos Germán Belli”. Poesía latinoamericana contemporánea: (Borges, Neruda, Vallejo, Huidobro, Rojas, Belli, Rubio, Hahn). Guatemala: Instituto de Estudios de la Literatura Nacional, Universidad de San Carlos Guatemala, Facultad de Humanidades, Sección de Publicaciones, 1983. 61-73. Analiza los poemas de Dentro \& fuera. Este artículo fue leído en el XCIII Annual Congress of the Modern Language Association of America (MLA) en Nueva York, Diciembre de 1978.

Duchesne, Juan. "Mensaje desde la Bética no bella: Boda de la pluma y la letra, de Carlos Germán Belli”. Escritura (Caracas) 10.19-20 (1985): 151-60. Analiza varios de los poemas así como también "El pesapalabras" que sirve de introducción a Boda [...]. El autor examina la angustia y sufrimiento del narrador del poema y las adversidades que enfrenta en su "Bética no bella" - la ciudad de Lima.

Escobar, Alberto. "En pos de la estructura." La partida inconclusa, o, La lectura literaria. $2^{\mathrm{a}}$ ed. Lima: Instituto Nacional de Cultura, 1976. 82-96. Analiza "Warma Kuyay" de José María Arguedas y "Algún día el amor" de Belli.

Espina, Eduardo. "Carlos Germán Belli y la dificultad". El pesapalabras: Carlos Germán Belli ante la crítica. Miguel Angel Zapata, ed. Lima: Tabla de Poesía Actual, 1994. 15564. Analiza varios versos y concluye: "En esta suma de riesgos y trampas, la lírica de Belli emerge como un criptograma fascinante (como 'escriptura'), donde lo imaginario es por fin protagonista de su propio acontecer". 
Espinoza Suarez, Gabriel, ed. "Carlos Germán Belli” Posdata 1.12 (domingo 17 de enero 1993): 1-4. Incluye: "Poema", "Asir la forma que se va", fragmento de "Canción en alabanza del bolo alimenticio y en reprimenda del alma" y "Página autobiográfica" de Antología personal; "De los recuerdos" de Acción de gracias; y "Carlos Germán Belli: una poesía para tiempos difíciles" por Mario Vargas Llosa.

Evans, Simón. "Carlos Germán Belli" El peruano suplemento cultural Revista (Lima) 7 de julio 1993: 2-3. Incluye notas biográficas con comentarios de CGB acerca de su trayectoria literaria. "Solitario entre los poetas de la década del cincuenta, Carlos Germán Belli (1927) no ha conocido seguidores ni discípulos. Su poesía ha transcurrido desde el comienzo, ajena a modas o artificios renovadores, tomando una dirección propia y original".

F. T. H. "Carlos Germán Belli." La prensa, 7 días del Perúy del mundo(Lima) 28 de setiembre 1969: 29. Belli ha creado un estilo muy propio al combinar la forma de la poesía española de hace varios siglos con temas que comunican angustia, y ocasionalmente, algún placer del hombre moderno.

Falla, Ricardo. "Adán, Belli y Romualdo: Alienación y realidad”. La prensa (Lima) 11 de julio 1980: 10. El contenido y la forma de la poesía de Belli se ocupan de temas concretos teniendo al mismo tiempo cierta conexión con el concepto de alienación. El autor define esta alienación como: "Concepto que caracteriza la transformación de los fenómenos y relaciones, de cualquier signo, en algo distinto de lo que en realidad son".

Fernández Moreno, César, coordinación e introducción. América Latina en su literatura. $1^{\mathrm{a}}$ ed. México: Siglo XXI Editores; France: Unesco, 1972. Mencionado por: George Robert Coulthard ("Pluralidad cultural: influencias literarias") 71. Fernando Alegría (“Antipoesía latinoamericana") 257. Roberto Fernández Retamar ("Intercomunicación y nueva literatura: consolidación de la novela") 323. Mario Benedetti ("Temas y problemas: en un pie de igualdad") 355. José Miguel Oviedo ("Maestros y discípulos de la disidencia") 436.

Franco, Jean. "La Poesía posterior al modernismo: otros poetas". Historia de la literatura hispanoamericana a partir de la independencia. Carlos Pujol, trad. Barcelona: Ariel, 1975. 328-29. Sitúa la poesía de Belli entre la más original de Hispanoamérica por su sensibilidad al tratar sobre los efectos que producen los tiempos modernos en nuestra vida privada. Su poesía expresa angustiay es deliberadamente arcaica; puede ser desesperada a veces, y utilizar un lenguaje violento otras, como lo hace en el poema "Plexiglás".

Galaz-Vivar Welden, Alicia. "Carlos Germán Belli o la farsa parlante paródica". Alta marea: introvisión crítica en ocho voces latinoamericanas. Madrid: Betania, 1988. 1-16. A través de varios poemas estudia el lenguaje, sintaxis, vocabulario e influencias en la poesía de Belli: "Belli participa de una tónica irrespetuosa, en una desacralización del mundo de empaque parriano, pero su inspiración ha bebido en diversas fuentes y emerge originalísima aún en sus plagios que él confiesa, con autenticidad fascinante".

Garganigo, John. "Carlos Germán Belli”. El pesapalabras: Carlos Germán Belli ante la crítica. Miguel Angel Zapata, ed. Lima: Tabla de Poesía Actual, 1994. 79-86. "El elemento principal de su obra es la tensión producida por los múltiples puntos de enfoque, contrastes chocantes y sutiles juegos de claroscuro en un nivel temático y en planos espaciales y temporales". También en: Antología crítica. Selección y notas de John Garganigo. Hanover, N.H.: Ediciones del Norte, 1988. 5-13. 
Garibaldi, F. "Poesía y crítica en Carlos Germán Belli". Incontri (Lima) 123 (giug. 1978): 34-35. Estudio general de la obra de Belli concentrándose primeramente en Dentro \& fuera y !Oh Hada Cibernética!

Gazzolo, Ana María. "Belli: una nueva experiencia". Reseña de El buen mudar. El comercio

(Lima) 5 de abril 1987: C-15. El estilo de Belli continúa siendo el mismo, sin embargo, en este libro combina prosa y verso: "Los textos en prosa de Belli no están a la altura de sus poemas, llenos de ritmo y dominio singular, y siempre sobresalientes".

"Carlos Germán Belli: poeta por partida doble”. Oiga 30 de marzo 1987: 70-71. Escrito en ocasión de la presentación de Más que señora humana y El buen mudar. "El estilo de Carlos Germán Belli no tiene parangón en la poesía de este siglo en el Perú". "Estructura de un poema de Carlos Germán Belli: 'Sextina del mea culpa". Creación y crítica 15 (agosto 1973) [sin numeración]. Analiza la estructura semántica de este poema y el tema, "mea culpa", indicado en el título y que enfatiza el narrador, el hijo, en el primer verso cuando dice: "Perdón, papá, mamá". Alcanza la expiación de su culpa a través de la muerte.

La Generación del 50 en la literatura peruana del siglo XX. $1^{\mathrm{a}}$ ed. La Cantuta, Chosica, Lima: Universidad Nacional deEducación "Enrique Guzmán y Valle”, Facultad de Humanidades y Artes, Dept. Académico de Literatura, 1989. vol. 1(189-91). Contribución importante al estudio de la Generación del 50. Informa sobre el ambiente político, social y económico de la época y comenta sobre el lugar que ocupa esta generación literaria en la poesía peruana del siglo veinte. Menciona a Belli varias veces y en la sección "Testimonios" incluye unas palabras del poeta y el poema "Sextina de los desiguales". Goic, Cedomil. Historia y crítica de la literatura hispanoamericana. 3 vols. Barcelona: Editorial Crítica, 1988. vol. 3 (243-44). "El humor negro matiza fuertemente el temple de ánimo de su poesía".

González Vigil, Ricardo. "Belli, el pesapalabras" El comercio (Lima) 16 de julio 1994. En la sección "Nuevas publicaciones" comenta sobre el libro editado por Miguel Angel Zapata: El pesapalabras: Belli ante la crítica. "No puede ser más suculento: aportes de Escobar [...] eso sí, debería haberse abordado en la Presentación los reparos que algunos críticos han formulado contra Belli. Convenía pesarlos, sopesarlos, desmenuzarlos, deshacerlos".

"Belli, la forma desasida". La crónica (Lima) 1 de diciembre 1979: 5. Se concentra en Asir la forma que se va y En alabanza del bolo alimenticio. La forma es clásica pero el mensaje y la esencia son contemporáneos. Encontramos tres temas principales en el poema En alabanza [...]. Un paisaje agradable, confrontación u oposición entre cuerpo y alma y evocación a las musas. A través de estos poemas Belli demuestra la maestría que ha alcanzado como poeta. También en: El pesapalabras: Carlos Germán Belli ante la crítica. Miguel Angel Zapata, ed. Lima: Tabla de Poesía Actual, 1994. 195-98.

"En torno de Belli". El comercio, Suplemento dominical (Lima) 16 de enero 1983: 16. Reseña de Canciones y otros poemas. Sitúa a Belli entre los mejores poetas peruanos contemporáneos. En este libro hay cierto énfasis en el tema erótico. A pesar de sufrir el hombre puede vislumbrar el cielo durante el sueño, rezando, o a través del placer erótico. 
"Reconocimiento de Belli". El comercio, Suplemento dominical (Lima) 29 de junio 1986: 19. El reconocimiento de Belli internacionalmente de debe a la originalidad de su poesía. Ella reside en la mezcla de formas antiguas (tradición) con formas nuevas (innovación). Señala también los temas sociopolítico y religioso presentes en su obra. $\mathrm{El}$ autor considera que hacer, o crear, poesía religiosa (como arte y no como enseñanza moral) es probablemente el reto más grande para un poeta.

Hahn, Oscar. "Carlos Germán Belli: ese rico amanuense del Perú". El pesapalabras: Carlos Germán Belli ante la crítica. Miguel Angel Zapata, ed. Lima: Tabla de Poesía Actual, 1994. 229-31. Se ocupa del lenguaje y estilo señalando que en su poesía: "Confluyen dos códigos poéticos: el del manierismo barroco y el de la modernidad". También en: Tabla de poesia actual 1 (primavera boreal de 1992): 31-33.

Reseña de En alabanza del bolo alimenticio. Hispamérica 10.29 (1981): 117-18. Notamos en este poema que la actitud del narrador ha cambiado. Ha aceptado su suerte y ya no está en conflicto con la sociedad. La lucha y el conflicto del narrador en los poemas anteriores de Belli complementan la originalidad del lenguaje. Esta combinación produce cierta tensión en el lector la cual es muy efectiva, sin embargo, con este cambio de actitud del narrador Belli continúa sorprendiendo al lector con su habilidad creativa. Higgins, James. "Carlos Germán Belli." The Poet in Peru: Alienation and Quest for a Superreality. Liverpool, Great Britain: F. Cairns, 1982. 46-64. Examinando varios de los poemas el autor señala que la originalidad de Belli reside en el uso de lenguaje clásico, a veces arcaico, y metros y técnicas que nos recuerdan la poesía española del Siglo de Oro, con coloquialismos e imágenes y temas contemporáneos. Entre los temas que encontramos en su poesía tenemos frustración, alienación, fracaso, lucha constante para poder sobrevivir y la incapacidad de alcanzar logros personales. Una de sus fallas consiste en la repetición de ciertas imágenes y expresiones, pero Higgins concluye: "Yet this failing, as much as his virtues, provides us with a key for understanding his work."

"El mundo poético de Carlos Germán Belli a través del poema "Contra el estío"". Literatura de la emancipación hispanoamericana y otros ensayos. Memoria del XV Congreso del Instituto de Literatura Iberoamericana, $2^{a}$ sesión en Lima (9-14 de agosto de 1971). Lima, Perú: Universidad Nacional Mayor de San Marcos, Dirección Universitaria de Biblioteca y Publicaciones, 1972. 179-83. Sitúa a Belli entre los mejores poetas latinoamericanos de su tiempo. Analizando "Contra el estío" encuentra que el poema muestra influencias clásicas que nos recuerdan a la poesía española de la Edad de Oro, sin embargo, el tema es muy moderno: la lucha del individuo para alcanzar felicidad, para poder lograr una existencia libre del diario afán por sobrevivir.

" "No me encuentro en mi salsa': alienación y poesía en Carlos Germán Belli”. El pesapalabras: Carlos Germán Belli ante la crítica. Miguel Angel Zapata, ed. Lima: Tabla de Poesía Actual, 1994. 87-117. Analiza varios poemas y concluye: "No sólo se ha forjado una voz personal que lo distingue de los demás poetas hispanohablantes de su época, sino que su manejo magistral del lenguaje y del ritmo transmuta una temática limitada y hasta banal en una poesía de significado universal y duradero".

"Los poetas enajenados". Insula 29.332-33(julio-agosto 1974): 7-10. Comenta sobre la poesía de Eguren, Vallejo, Moro, Adán, Delgado, Romualdo y Belli en quien encuentra una marcada influencia de Vallejo. Una persona solitaria enfrentando un mundo hostil. 
“The poetry of Carlos Germán Belli". Bulletin of Hispanic Studies 47 (Oct. 1970): 327-39. Un detallado análisis de El pie sobre el cuello (Montevideo 1967). "His poetry revolves obsessively around the same basic situations, for this is a man trapped in an intolerable predicament from which he cannot break free." Básicamente el mismo -artículo bajo el título: "Carlos Germán Belli: una introducción a su poesia" apareció en Textual (Lima) 4 (junio 1972): 59-63.

"Poetry Pure and Impure". A History of Peruvian Literature. Liverpool: F. Cairns, 1987. 256-92. Páginas 283-92 de este capítulo están dedicadas a Belli. El autor ofrece un estudio general sobre la obra de Belli y analiza varios de sus poemas. Considera a Belli un poeta destacado y artísticamente consumado; un poeta que ha dominado el lenguaje y desarrollado un estilo definido: "For Belli poetry seems to be a kind of personal catharsis, a means of purging the pain that life causes."

Hill, W. Nick. "A la zaga de Carlos G. Belli". La Chispa '83, Selected Proceedings. Gilbert Paolini, ed. The Fourth Louisiana Conference on Hispanic Languages and Literatures. New Orleans: Tulane University, 1983. 125-33. "El signo de la modernidad poética en que se cifra la persona belliana es la pretención de conjugar los orígenes y la actualidad de una realidad americana, y que mediante la vanidad de la empresa afirma y confirma su modernidad".

"Carlos Germán Belli deportista del infinito". Discurso 8.1 (1991): 147-57. Analiza "El guardameta" y "Estadio Vaticano". Hill señala las influencias y características vanguardistas, maneristas y modernistas en su obra: "Belli es un coleccionista: de fórmulas, de personas, de épocas enteras". También en: El pesapalabras: Carlos Germán Belli ante la crítica. Miguel Angel Zapata, ed. Lima: Tabla de Poesía Actual, 1994. 141-53.

"El pastor/poeta en el 'microuniverso' belliano". Revista de crítica literaria latinoamericana 10.20 (1984): 171-88. Examina poemas de El pie sobre el cuello, Por el monte abajo y !Oh Hada Cibernética! La ciudad de Lima provee la base, real e imaginaria, del "microuniverso" del narrador de los poemas el cual se expresa combinando tradiciones clásicas y modernas: "El problemático mensaje estético que comunica la poesía de Belli a través de su 'microuniverso', lejos de la negación, termina igualando y poniendo en comunicación las dos tradiciones [...]. En verdad, no se sabe si la obra metairónica de Belli traduce un ejemplo concreto del 'fin de la idea de arte moderno' o si da con los inicios de una de las direcciones de la próxima poesía hispanoamericana, que todavía no tiene nombre".

Tradición y modernidad en la poesía de Carlos Germán Belli. Madrid: Pliegos, 1985. 230. Estudio minucioso de la obra de Belli desde Poemas hasta En alabanza del bolo alimenticio. Presentada originalmente como tesis de doctorado, University of Iowa, 1980. 242.

Horanyi, Matyas. “'A otra cosa' difícil alternativa de la poesía peruana”. Actas del Simposio Internacional de Estudios Hispánicos, (Budapest, 18-19 de agosto de 1976). Budapest: Akademiai Kiado, 1978. 285-90. Estudio de la poesía peruana concentrado en la llamada "Generación del 50" cuya poesía marcó un nuevo derroteo y dio nueva orientación a la poesía peruana. El autor se concentra en los cuatro poetas que considera como los mejores representantes de esta generación: Belli, Delgado, Romualdo y Sologuren. 
Ibañez Langlois, José Miguel. "Belli: Sextinas y otros poemas". Poesía chilena e hispanoamericana actual. Santiago: Editorial Nascimiento, 1975. 301-305. El estudio se concentra en el lenguaje y temas de estos poemas. Belli al revelar su visión del mundo, injusticia social y marginalidad evoca en el lector algunas historias de Kafka. Su estilo probablemente tendrá pocos seguidores, sin embargo, ha probado ser honesto, efectivo y de gran calidad y fuerza reveladora. El mismo artículo fue publicado en El mercurio (agosto 16, 1970): 3, bajo el seudónimo de Ignacio Valente.

"La poesía de Carlos Germán Belli". Poesía chilena e hispanoamericana actual. Santiago: Editorial Nascimiento, 1975. 295-300. Considera a Belli el poeta más interesante del Perú a pesar de su relativamente pequeña producción literaria. Belli muestra una marcada influencia de Garcilaso y Góngora y algunos lectores podrían tener cierta dificultad en comprender su poesía. Utiliza un lenguaje preciso y está consciente de su creación artística. Su poesía revela un mundo muy personal lleno de angustia, experiencias y una buena cantidad de ironía. Su fracaso podría ser el uso contínuo de ciertos símbolos que podrían convertirse en repetitivos y mecánicos. También en $E l$ pesapalabras: Carlos Germán Belli ante la crítica. Miguel Angel Zapata, ed. Lima: Tabla de Poesía Actual, 1994. 233-38 y en El mercurio (29 de setiembre 1969) bajo el seudónimo de Ignacio Valente.

Kappatou, Rhegas. "E synchrone Latinoamerikanike poiese Karlos Cherman Belli". Stochoi 2.5-6 (genares-apriles 1980): 4-5. Hace referenciaa varios poetas peruanos encontrando la influencia vanguardista una nota común en Vallejo y Belli. Señala también la mezcla de temas modernos con el uso de lenguaje barroco como otra característica belliana. Transcrito del griego.

La Torre, Alfonso. "La moderna angustia de Carlos Germán Belli". El comercio gráfico (Lima) 8 de julio 1964: 6. Para poder transmitir lo que el autor califica "moderna angustia", Belli ha asumido cierta forma de expresión.

Lasarte, F. "Pastoral and Counter-pastoral: the Dynamics of Belli's Poetic Dispair". Modern Language Notes 94 (1979): 301-20. Análisis del uso que Belli hace del lenguaje, temas y las diferencias/similitudes con la poesía pastoral renacentista: "Belli's poetry, then can be said to be an incomplete and ironic rewriting of the Renaissance pastoral."

Lastra, Pedro. "Después de Vallejo. Poesía de Carlos Germán Belli". La nación, Suplemento dominical (Santiago de Chile) 14 de mayo 1967: 5. Considera a Belli un importante representante de la poesía latinoamericana. Su uso efectivo del lenguaje y temas contemporáneos permite al lector identificarse con el punto de vista de la realidad y medio ambiente del poeta. Incluye tres poemas.

Lech, Jorge Miguel. "Búsqueda de la extemporaneidad". Pupitre (suplemento de El noticiero universal) junio 22 de 1985: 34-36. No fue examinado personalmente.

Legault, Christine. “'Plagio' y transgresión en la poética belliana”. El pesapalabras: Carlos Germán Belli ante la crítica. Miguel Angel Zapata, ed. Lima: Tabla de Poesía Actual, 1994. 21-40. "Nos proponemos aquí precisar los límites del plagio en la poética belliana y explorar su significación metapoética, limitando exclusimamente nuestras referencias a textos de Góngora".

"Poesía hispanoamericana posvanguardista y manierismo: dimensiones formales de una intertextualidad cultural". Tesis doctoral, University of Iowa, 1987. 144. Elabora sobre el barroco y el manerismo y presenta un análisis textual de Góngora, Belli y Lihn. 
Lerín, Manuel. "Poesía de Belli”. Reseña de El pie sobre el cuello. El nacional (México), 9 de agosto 1964: 15. "Esta poesía no puede perderse de vista, su hondura, su trazo poco comunes, son válidos y elogiosos".

Lévano, César. "Una primavera florida." Caretas (Lima), 18 de setiembre 1964: 26-29. Belli piensa que la poesía debe tener cierta función o propósito social pero debe adherirse siempre a la forma artística. Él, Belli, espera una sociedad más humana. El autor cita a Vargas Llosa: "Creo que en Belli tenemos un poeta realmente extraordinario".

Lihn, Enrique. "Carlos Germán Belli”. Jo Ann Engelbert, trans. Review 31 (Jan-Apr) 1982: 6-9. Se refiere al manerismo en Belli y concluye: "Perhaps the most eccentric poetic language to arise in the last twenty-five years. And also, perhaps, the one most deeply anchored as a thorn in the flesh in the fundamental problems of Latin America, where all of us live and write 'with a foot on our throat'." Incluye siete poemas traducidos por Luis Harss.

“En alabanza de Carlos Germán Belli". Inti 18-19(1983-1984): 131-34. Por el hecho de que Belli escriba una poesía formal no se debe de interpretar su obra como personal. Considera su vocabulario y sintaxis maneristas. Publicado también en Antología personal páginas 223-27; bajo el título: "Carlos Germán Belli: imaginar la realidad" en Cauce 1.11 (24 de abril-7 de mayo 1984): 36-37; y también en: El pesapalabras: Carlos Germán Belli ante la crítica. Miguel Angel Zapata, ed. Lima: Tabla de Poesía Actual, 1994. 205-10.

Literatura y sociedaden el Perú. Antonio Cornejo Polar [... etal.]. $1^{\mathrm{a}}$ ed. 2 vols. Lima: Hueso Húmero Ediciones, 1982. En el capítulo "La poesía" - vol. 2: "Narración y poesía: un debate" Belli es mencionado varias veces y su obra comparada con la de otros poetas. En este debate también tomaron parte: Washington Delgado, Mirko Lauer, Marco Martos, Abelardo Oquendo, y Mario Montalbetti como moderador.

Llaque, Paul. Reseña de Antología crítica. Revista de literatura latinoamericana 15.30 (1989): 361-63. "La relevancia de esta antología se advierte en el hecho de que es lo suficientemente ejemplificada [...] al mismo tiempo que ofrece las líneas esenciales de lapreocupación poéticabelliana, así como sus procedimientos expresivosmás destacados".

Loayza, Luis. "La poesía de Carlos Germán Belli”. Expreso (Lima) 23 de noviembre 1962:

11. Escrito poco tiempo después de la publicación de la $2^{\mathrm{a}}$ ed. de !Oh Hada Cibernética! Poesía escrita con gran cuidado y preocupación por la forma que transmite al mismo tiempo una visión realista del mundo. El poeta hábilmente expresa su angustia, humillación, desaliento y desesperación. El toque de ironía es también un elemento importante en la poesía de Belli: "Su poesía no es sólo una bella construcción verbal, sino la expresión profunda de una vida y un testimonio lacerante sobre nuestra sociedad".

M. P. R. "En el coto de la mente". Panorama (Buenos Aires) 8.188 (diciembre 1970): 53.

Escrito en ocasión de la publicación de Sextinas y otros poemas. Considera a Belli el verdadero sucesor de Vallejo. Señala la sintaxis, el vocabulario e imágenes que se encuentran en su poesía.

M. V. R. "Nuevo poemario de Carlos Germán Belli". Reseña de En alabanza del bolo alimenticio. Expreso(Lima) 17 de diciembre 1979: 11. Se concentra en la versificación, temas, y lenguaje empleado en estos poemas. Señala que Belli no utiliza tan a menudo en ellos las expresiones coloquiales que encontramos en sus poemas anteriores.

Margenot, John B., III. "Lo autorreferencial en varios poemas de Carlos Germán Belli”. 
Discurso literario 5.1 (1987): 139-53. Señala la influencia vanguardista, vocabulario, semántica y sintaxis en la poesía de Belli y se concentra en Asir la forma que se va y En alabanza del bolo alimenticio: "El poema como mundo autónomo y acto de autorrealización artística comprende el núcleo de la poética autorreferencial de Belli".

Martos, Marco. "Carlos Germán Belli y la metafísica del amor". La república 29 de marzo de 1987: 42-43. No fue examinado personalmente.

"Un poeta revisa a otro poeta: Belli y el paraíso terrenal". Punto aparte (Lima) 27 de enero 1991: 16. "Lo admirable de su escritura es que con elementos diferentes a los de cualquier otro escritor latinoamericano contemporáneo, con un léxico y una adjetivación que parecen a primera vista pobres, pero con un conocimiento de la tradición verdaderamente excepcional, internaliza su voz en los meandros del idioma".

"Tres poetas platónicos y conceptistas" Gestión (Lima) 1 ro. de julio 1993 (en la sección Opinión). "A Belli lo consideramos un poeta de estirpe platónica como lo son Sologugen, Eielson, Bendezú, Varela, Destua, Ruiz Rosas, Ferrari, pero es con estos dos últimos que está más emparentado en el cuidado de la palabra, en las reminiscencias clásicas en la admiración por Quevedo y Góngora. A estos tres poetas los hemos bautizado como platónicos conceptistas".

Maurer, Karl. "Notes on Carlos Germán Belli". Plaza: revista de literatura (Cambridge, Mass.) 12 (primavera 1987): 39-46. El autor señala la dificultad que significa traducir la obra de Belli y el riesgo que se corre de perder, o cambiar, el significado de palabras claves al traducir sus poemas. Analiza varios poemas y considera a Belli un diestro escritor: "Belli's entire oeuvre (as critics have noticed) is a kind of linguistic 'system,' in which every image becomes a syntactic sign, a formula, the center of a far-reaching linguistic web."

Maurial, Antonio. “A propósito del último libro de Carlos Germán Belli”. Alpha 7 (1966): 54. Con Por el monte abajo Belli demuestra, una vez más, su calidad de escritor y la angustia de un hombre supeditado a una burocracia que lo oprime. Esta opresión inspira al poeta a contar su dolor y la angustia del individuo que vive bajo estas condiciones y circunstancias.

McMurray, George R. "The Andean Highlands - Peru." Spanish American Writing Since 1941: a Critical Survey. New York: Ungar, 1987. 189. Varios poetas son estudiados en este segmento. Acerca de Belli afirma: "Perhaps Peru's most original poetic voice since Vallejo, Belli invents his own language, difficult at times for the foreign reader."

Melis, Antonio. "La favola tecnologica di un poeta peruviano". L'indice del libri del mese 1 (ottobre 1984): 26. Desde Poemas (1958), Belli sigue siendo original y de gran autoridad artística. Sus poemas muestran influencia de Petrarca y elementos barrocos y renacentistas. Utiliza temas que tienen que ver con alienación, diferencia adquisitiva entre las clases, fracasos y logros, y el tema constante de su hermano inválido. Proyecta su angustia vital a un plano metafísico.

Meneses, Carlos. Reseña de Asir la forma que se va de Belli y Vida continua de Javier Sologuren. Hispamérica 9.27 (1980): 115-16. Reseña de Cuadernos de hipocampo, colección compuesta por trabajos de los mejores poetas de la época. Cada uno de los poetas ha escogido lo que considera lo mejor de su producción literaria. La compilación de estos "cuadernos" formará el "Libro de las Decenas". Acerca de Belli afirma que se 
encuentra entre los poetas hispanoamericanos más leídos. Su prestigio haaumentado con el tiempo y a pesar de que a menudo utiliza los mismos temas, su poesía es siempre nueva. Entre los poemas escogidos para esta colección tenemos: "Canción en alabanza del bolo alimenticio y en reprimenda del alma", "!Oh Hada Cibernética!" y "La sextina del mea culpa".

Meza C., Luis Antonio. "Ensayo-novela, poesía” El comercio (Lima) 22 de junio 1995. En cuanto a Belli, se ocupa de Un giorno l'amore, la última traducción al italiano de parte de su obra: "No creemos necesario entrar en mayores honduras sobre el estro poético de este notable representante de la lírica peruana en la segunda mitad del siglo, pues es autor que cada día no sólo se hace más conocido, sino que, a la par, se ve incrementar el interés de los estudiosos por su obra; lo que, en ambos casos, resulta muy merecido en nuestra opinión".

Mirán, Diego. "Belli, poeta del desvivir". Reseña de !Oh Hada Cibernética!. El comercio, Suplemento dominical (Lima) 25 de noviembre 1962: 9. En estos poemas persevera el sentimiento de abandono, desamparo e impotencia. El Hada Cibernética equivale a la esperanza, es la que un día introducirá el cambio.

Monroy Cervantes, Javier. "Reincidente Belli: torno de hablante". Oiga (Lima) 492 (23 de julio de 1990): 59-61. Considera que !Oh Hada Cibernética!, El pie sobre el cuello, Sextinas y otros poemas, En alabanza del bolo alimenticio, El buen mudar y En el restante tiempo terrenal son las mejores obras de Belli y concluye: "Hoy, el poeta [...] regresa para restituir al espacio poético local su (editorialmente) cíclica cuota de sorprendencia creadora".

Moreno-Durán, R. H. "En alabanza del humano bofedal" Como el halcón peregrino: la augusta sílaba. $1^{\text {a }}$ ed. Santafé de Bogotá: Aguilar, 1995. 281-87. Sigue la trayectoria de Belli y su amistad a través de los años con el poeta.

Muñoz Martineaux, Ronnie. “'Sextinas' de Germán Belli”. Nueva crónica (Lima) 26 de marzo 1974: 13. Un alarido patético. El poeta grita y se queja de su ambiente. Existe dolor, ironía y, a veces, pesimismo.

Nerozzi, Carlotta. "La lingua poetica di Carlos Germán Belli". Tesi di laurea in lingua e letterature straniere, Facolta di Magisterio, Universita degli Studi di Firenze. Anno accademico 1983-1984. 316. No ha sido examinada personalmente.

Núñez, Estuardo. La literatura peruana en el Siglo XX (1900-1965). México: Editorial Pormaca, 1965. 58-59. Estudio de prosa y poesía peruana. Sitúa a !Oh Hada Cibernética! entre la mejor poesía peruana. Considera que Belli emplea un lenguaje original. Mezcla intensa emoción e ironía, comparte sus experiencias y visión del mundo y de la vida. Su poesía es la más sobresaliente en los últimos veinte años. Belli es también mencionado en las páginas 49, 55, 57, 232, 233.

O’Hara, Edgar. "Las coincidencias de la exactitud". La república 23 de octubre 1988: 6. No fue examinado personalmente.

Reseña de Canciones y otros poemas. Debate 19: 81-82. Analiza los temas y afirma que al final de los poemas Belli confiesa, o reconoce, diferentes clases de fracasos pero no se considera vencido: "El tránsito de su poesía se realiza de la adquisición de la forma a la elevación religiosa que el yo que habita esa forma intenta infructuosamente".

Ollé Nava, Carmen. “¿Existe una poesía pura?” La Generación del 50 en la literatura peruana 
del siglo XX. 1a. ed. La Cantuta, Chosica, Lima: Universidad Nacional de Educación "Enrique Guzmán y Valle", Facultad de Humanidades y Artes, Dept. Académico de Literatura, 1989. vol. 1 (55-81). La autora estudia varios poetas. Señala puntos en común, en lo que se refiere al tratamiento de algunos temas, entre Belli y Jorge Guillén y afirma: "Por la ausencia del encadenamiento lógico la obra poética de Vicente Aleixandre se emparenta con la de Javier Sologuren y la de Carlos Germán Belli —el representante surrealista del grupo. Pero sobre todo por la presencia de elementos contrapuestos que hacen estallar la calma que aparentemente cubre una realidad que ellos rechazan".

Oquendo, Abelardo. "Belli: una coyuntura dificil". El comercio, Supplemento dominical (Lima) 6 de setiembre 1970: 26. El autor considera que con Sextinas y otros poemas, tanto la persona poética como los temas se han agotado y ahora Belli debe encontrar otro derroteo a su poesía.

"Belli, una Poesía desgarrada". El comercio gráfico (Lima) 19 de noviembre 1962: 8. Escrito a raíz de la publicación de !Oh Hada Cibernética! El autor considera esta poesía desgarradora, la angustia personal se refleja a través de la obra. Existe una serie de contrastes en ella como es el uso de un lenguaje arcaico combinado con temas contemporáneos, la visión negativa de la vida y al mismo tiempo esperanza de seguir viviendo. Belli artísticamente comparte su visión del mundo y su realidad.

"Carlos Germán Belli: El pie sobre el cuello". Revista peruana de cultura 3 (octubre 1964): 145-47. Con esta obra la poesía de Belli ha alcanzado su mejor expresión. El poeta es más personal y se preocupa más por su situación y por la invalidez de su hermano. Generalmente la poesía de Belli no describe el paisaje ni alude a los colores y esto es más prevalente en esta obra. Debido a la sustancia y lenguaje de su obra ésta debe ser leída, y considerada, en su totalidad para apreciarla mejor.

Reseña de Enalabanza delboloalimenticio. Revista de críticaliterarialatinoamericana 6.12 (1980): 288-90. Belli, uno de los mejores poetas peruanos, empieza a declinar con Sextinas y otros poemas. Los temas y el lenguaje, que fueron tan innovadores en sus poemas anteriores, ahora se hacen repetitivos. A En alabanza del boloalimenticio le falta la vitalidad e intensidad de sus libros anteriores; da la impresión de ser artificial y demasiado convencional; no tiene el impacto de sus previas obras.

Orrillo, Winston. "Carlos Germán Belli: por la desesperación a la esperanza". Reseña de $E l$ pie sobre el cuello. Correo (Lima) 1 de junio 1964: 12. Sus poemas están basados en la realidad al mismo tiempo que se expresan en forma perfecta. Su poesía es innovativa por su significadoy significación. Belli utiliza temas de dolory sufrimiento para producir en el lector sentimientos de rebelión y protesta, pero su mensaje siempre es la esperanza.

"Poesía peruana actual: dos generaciones". Cuadernos hispanoamericanos 228 (diciembre 1968): 620-62. El autor evalúa varios poetas de las décadas de los 50 y 60 . Considera que el estilo de Belli, una mezcla de lenguaje arcaico y temas modernos, es virtualmente imposible de imitar y que sus críticos tienen dificultad en cuanto se refiere a su afiliación poética. El estilo de Belli ha de ser su éxito o su ruina. Incluye: "Segregación no. 1" y "Amanuense".

Reseña de El pie sobre el cuello. El comercio (Lima) 25 de octubre 1967: 2. Protesta 
es un tema recurrente en la poesía de Belli; para él no existe el placer, paz o conformismo; es un individuo oprimido y agobiado por el destino. El lenguaje que utiliza es una forma de protesta, un modo de no darse por vencido y conformarse con su existencia. Al igual que Vallejo en Poemas humanos, Belli asume, con horror y fascinación, la difícil tarea de vivir.

Ortega, Julio. “Calidad expresionista de Belli”. Laprensa, 7 dias del Perúy del mundo(Lima) 24 de julio 1966: 34. Por el monte abajo solidifica la posición de Belli como el mejor poeta peruano de su tiempo. El lenguaje diferente, las formas clásicas y modernas que emplea, la angustia, su percepción de la realidad y su busca constante de valores sitúa su obra entre la mejor de América Latina.

“Carlos Germán Belli”. Figuración de la persona. Barcelona: Edhasa, 1971. 12936. En el capítulo "Lectura de la tradición" analiza: Poemas, Dentro \& fuera, !Oh Hada Cibernética!, El Pie sobre el cuello y Por el monte abajo. Este artículo, ligeramente modificado, sirvió de introducción a Sextinas y otros poemas. Santiago de Chile: Editorial Universitaria, 1970, y apareció en Imagen 33 (setiembre 1968): 24.

"Carlos Germán Belli". La prensa literaria (Managua) 8 de noviembre 1975: 4-5, 9. Belli ha logrado un estilo muy personal, una mezcla de formas utilizadas por la poesía española de la Edad de Oro con expresiones locales, lengua barroca e ironía. Se centra en la persona poética quien expresa su realidad utilizando temas de dolor y sufrimiento, los cuales están presentes a través de sus poemas. Su poesía da la impresión de claroscuro. Incluye cuatro poemas.

"Carlos Germán Belli prepara su poesía completa". La prensa, 7 dias del Perú y del mundo (Lima) 12 de setiembre 1965: 30. El próximo libro de Belli, que pronto saldrá a la luz, está entre los más valiosos de la literatura peruana contemporánea. Su estilo único, creatividad y su uso del lenguaje le ha merecido un lugar entre los mejores poetas de su tiempo. Al igual que Vallejo, su poesía refleja su preocupación por la existencia del hombre y su lucha en la sociedad.

"Poesía de Belli". Expreso (Lima) 28 de setiembre 1967: 13. La poesía de Belli es a la vez expresionista y neorrealista. Lo singular de su poesía radica en el hecho de que no sigue normas establecidas sino, más bien, crea las suyas propias. El individualismo de sus primeros poemas hasido reemplazado por una poesía de dimensión más humanista y social que refleja la realidad que lo rodea.

"La poesía de Carlos Germán Belli". Temas (Montevideo) 13(1967): 54-55. Su poesía critica la situación social de su país. Utiliza un lenguaje arcaico mezclado con términos modernos y coloquialismos para expresar su dolor y frustración. De cierto modo nos recuerda la poesía de Nicanor Parra y Jaime Sabines y también, aunque por razones diferentes, la de Juan Cunha. También en: El pesapalabras: Carlos Germán Belli ante la crítica. Miguel Angel Zapata, ed. Lima: Tabla de Poesía Actual, 1994. 185-93.

"La poesía peruana actual". Cuadernos americanos 156 (enero-febrero 1968): 191200. Estudia la poesía peruana desde Eguren y Vallejo y considera a Belli el mejor poeta peruano de su generación. Influenciado en un principio por elementos surrealistas, emplea formas clásicas para contar sus experiencias y realidad.

Oviedo, José Miguel. "Belli: magia y exasperación". El comercio, Supplemento dominical (Lima) 29 de julio 1962: 5. A partir de !Oh Hada Cibernética! (1961), Belli deja atrás 
la influencia vanguardista para convertirse en uno de los mejores poetas peruanos de los últimos veinte años. Se hace muchas preguntas y llega a la conclusión que el mundo se compone de amos y esclavos, de poderosos y necesitados. Leyendo a Belli nos encontramos con un poeta doliente, uno de los más afligidos, importantes y originales en la literatura peruana desde Martín Adán.

"Belli: más pavor, más asfixia". El comercio, Suplemento dominical (Lima) 24 de mayo 1964: 8. Considera El pie sobre el cuello una obra excepcional en la que el autor, combinando formas clásicas con terminología moderna y localismos, expresa de una forma efectiva la falta de igualdad e injusticia social, la angustia y sufrimiento que padece. También en: El pesapalabras: Carlos Germán Belli ante la crítica. Miguel Angel Zapata, ed. Lima: Tabla de Poesía Actual, 1994. 181-84.

"Belli: otra inmersión en el mismo infierno". El comercio, Suplemento dominical (Lima) 18 de setiembre 1966: 22. Con Por el monte abajo Belli confirma, nuevamente, el lugar que ocupa entre los poetas más originales y profundos de la América Española. $\mathrm{Al}$ igual que sus obras previas, ésta comunica su angustia y sufrimiento. Su estilo y lenguaje nos recuerdan la poesía española de la Edad de Oro.

"El Cuerpo del surrealista: Belli". El comercio, Suplemento dominical (Lima) 18 de setiembre 1960: 5. Belli sigue fiel al surrealismo a pesar de que éste ya no gusta tanto al lector actual. El autor encuentra únicamente tres buenos poemas en Dentro \& fuera, pero la destreza de Belli en el uso del lenguaje y las interesantes experiencias que tiene para compartir deben ser alicientes para abandonar estilos caducos y escribir "poesía".

"Maestros y discípulos de la disidencia". América Latina en su literatura. César Fernández Moreno, ed. $3^{\mathrm{a}}$ ed. México, D.F.: Siglo Veintiuno, 1976. 436. "Carlos Germán Belli constituye un caso —un valor- aparte con su lenguaje (casi) neoclásico, con sus alegorías y retruécanos, sus cultismos y arcaísmos, que van desenvolviendo una visión absolutamente pavorosa de la vida interior y social".

Pantigoso, Manuel. "Lo arcaico y lo popular reúne poesía de Belli". La prensa (Lima) 5 de mayo 1980: 11. Breve análisis de su obra desde Poemas hasta En alabanza del bolo alimenticio.

"Carlos Germán Belli: profundización y espiritualidad de la forma". Expreso (Lima) 4 de mayo 1980: 28. Estudia el lenguaje, temas, simbolismo, etc., de la obra de Belli desde Poemas hasta Asir la forma que se va.

Paoli, Roberto. "Razón de ser del neoclasicismo de Carlos Germán Belli". Estudios sobre literatura peruana contemporánea. Firenze: Universita degli Studi di Firenze, 1985. 151-60. Considera que algunos de los temas principales de la poesía de Belli son autobiográficos y que a través de símbolos el poeta expresa sentimientos de inferioridad, ineptitud, y exclusión. El poeta se identifica con la víctima y comenta, negativamente, sobre las diferentes clases sociales. En su lenguaje mezcla formas clásicas, modernas y localismos de su país mostrando al mismo tiempo marcada influencia de Petrarca, Garcilaso, Góngora, Quevedo y de la poesía barroca y renacentista. Parte del estilo de Belli consiste en el uso de "fórmulas" y la utilización del tema ligado al sufrimiento. Hace mención también al manerismo en su poesía. Mencionado también en páginas 95,127,133,134,138,145,149,150. También en: Enlace 2 (1984): 16-20; Antología personal páginas 211-21; Historiay crítica de laliteratura hispanoamericana. Barcelona: Editorial Crítica, 1988. vol. 3 (267-71); La generación del 50 en la literatura peruana 
del siglo $X X .1^{\mathrm{a}}$ ed. La Cantuta, Chosica, Lima: Universidad Nacional de Educación "Enrique Guzmán y Valle", Facultad de Humanidades y Artes, Dept. Académico de Literatura, 1989. vol. 1 (124-31); y en El pesapalabras: Carlos Germán Belli ante la critica. Miguel Angel Zapata, ed. Lima: Tabla de Poesía Actual, 1994. 41-53.

Paoli, Roberto y Carlotta Nerozzi. "Introduzione". !O Fata Cibernetica! Reggio Emilia: Elitropia Edizioni, 1983. 11-18. No fue examinado personalmente.

Paredes Castro, Juan. "Belli: poesía y angustia". La crónica, Suplemento dominical (Lima) 9 de marzo 1969: 4. La poesía de Belli trata de temas que preocupan al hombre. Temas relacionados con la existencia como son: soledad, amor, angustia, frustración, muerte y búsqueda del conocimiento.

"Sufrir por todos". La crónica (Lima) 13 de agosto 1971: 23. La originalidad de Belli reside en la mezcla del barroco y formas clásicas con temas que expresan angustia, sufrimiento y el vacío de la vida moderna. Su esperanza de salvación reside en su sacrificio, el cual consiste en enfrentar la realidad con todo valor y luchar con la misma fuerza que tratan de dominarlo.

Passalacqua, Rose. "Amanuensis and Agency: Plagiary as Rhetoric in the Poetry of Carlos Germán Belli." Tesis de doctorado. Washington University in St. Louis, 1994. Contiene cinco capítulos: "Introduction: The Poor Amanuensis of Peru," "Cultured Primitive: the Development of the Persona in Belli's Early Poetry," "Amanuensis in Wonderland: the Cybernetic Fairy as Plagiary's Muse," "The Formal Body: Pleasure and the Erasure of Plagiary in the Later Work," $y$ "New Formalisms: Carlos Germán Belli and the Poetry of the Americas." El apéndice incluye 93 poemas y la versión en inglés de los mismos. Pichón Rivière, Marcelo. "Belli: un poeta en Buenos Aires”. Panorama 10 (diciembre 1972): 62. "Poeta visceral, pero también hacedor de un lenguaje increíblemente propio, donde se conjuga un léxico arcaizante con el habla popular limeña. Belli es sin duda uno de los más grandes poetas de Hispanoamérica".

[Pool], Víctor Emesto. “Un reciente poemario de Carlos Germán Belli”. La crónica (Lima) 27 de julio 1958: 5. En Poemas Belli no se adhiere a formas definidas, a veces sigue ciertas normas, y otras, improvisa.

Portugal, Ana María. "Belli y la poesía peruana a nivel continental”. Correo, suplemento Revista de la semana (Lima) 17 de diciembre 1967: 7. "En la 'extraña' poesía de Belli, los elementos que la componen van desde el letrismo, y el lenguaje gutural, para pasar al surrealismo en la búsqueda de un lenguaje propio".

Puig, Salvador. "Entre Vallejo y los clásicos". El comercio, Suplemento dominical (Lima) 7 de enero 1968: 35. Estudia principalmente El pie sobre el cuello en el cual encuentra la presencia, humana más que poética, de Vallejo mezclada con la madurez de un estilo propio. Su originalidad reside en la combinación de un estilo antiguo con temas contemporáneos para comunicar su punto de vista.

Quiroga Chávez, Natalio. “Claves para una lectura de Belli I” La crónica (Lima) 16[?] de diciembre 1986. (páginas no disponible) "En la presente nota nos interesa destacar, más bien, el significado de la obra. En esa dimensión puntualizaremos dos cosas: de un lado el contexto socio literario del poeta y del otro, la estrategia textual y temática".

“Claves para una lectura de Belli II” La crónica (Lima) 19 de diciembre 1986. (páginas no disponible) "Los elementos de la poética en Belli están signados por la búsqueda de la aprehensión de los elementos del yo. Este factor es el fundante en su retórica”. 
R. J. “Carlos Germán Belli: tradición y modernismo en la poesía”. La crónica (Lima) 12 de julio 1986: 19. "La poesía de Belli está considerada como la conjunción de lo ficticio y lo antiguo o tradicional, con lo nuevo y el mundo científico".

Rabí do Carmo, Alonso. "El tiempo terrenal de Carlos Germán Belli”. El peruano, sección revista 9 de diciembre 1990: 2. Reseña de la tercera edición de En el restante tiempo terrenal. El autor considera que aunque el estilo de Belli sigue siendo el mismo, en estos poemas se aprecia una actitud vitalista.

Reseña de Acción de gracias. Revista letras (Lima) 92-93 (1993): 420-21. “Acción de gracias es un viaje del poeta por todo su entorno íntimo: la madre [...], la casa [...], la familia [...], los amigos [...] motivo por el cual la cuota autobiográfica es particularmente decisiva".

Rebaza Soraluz, Luis. Reseña de Lenguaje en conflicto: la poesía de Carlos Germán Belli (1987) de Mario Cánepa y Antología crítica editada por John Garganigo. Hispamérica 19.56-57 (agosto-diciembre 1990): 193-98. Entre lo que dice el autor de estas obras tenemos: "El libro de Cánepa es válido en la minuciosidad con que observa su área de estudio" y "La Antología crítica es un libro de bella edición, útil y equilibrado en su manejo de las cantidades".

Rodríguez Padrón, Jorge. "La aventura poética de Carlos Germán Belli." Diario de las Palmas (Canarias) 11 de julio 1980: 23. Estudiando En alabanza del bolo alimenticio el autor encuentra que el uso que Belli hace del lenguaje, temas, antiguas formas poéticas, etc., produce una poesía distinta y muy personal y concluye afirmando: "[...] en su gran capacidad de riesgo y aventura habita su mayor virtud". También en: El pesapalabras: Carlos Germán Belli ante la crítica. Miguel Angel Zapata, ed. Lima: Tabla de Poesía Actual, 1994. 55-61.

Saínz de Medrano, Luis. "La penúltima poesía peruana: Carlos Germán Belli”. Lo real maravilloso en Iberoamérica: relaciones entre literatura y sociedad. José Ignacio Urquiza González, ed. Cáceres: Junta de Extremadura, Oficina Enclave 92: Dept. de Filología Hispánica, Universidad de Extremadura, 1992. 115-30. Señala las influencias en la obra de Belli y elabora sobre los temas, lenguaje e ironía que encontramos en su poesía. Analiza "Variaciones para mi hermano Alfonso", "!Oh Hada Cibernética!", "Segregación número 1" y otros poemas y afirma: "La poesía de Belli tiene una unidad sustancial”. También en: El pesapalabras: Carlos Germán Belli ante la crítica. Miguel Angel Zapata, ed. Lima: Tabla de Poesía Actual, 1994. 239-62.

Salas, Horacio. Reseña de En alabanza del bolo alimenticio. Cuadernos hispanoamericanos 369 (marzo 1981): 688-89. Su uso de formas clásicas y lenguaje arcaico es un modo de burla. Belli se esconde detrás de formas barrocas para expresar el dolor y sufrimiento que experimenta la sociedad actual, comunicando de esta forma, la realidad del individuo.

Salazar Bondy, Sebastián. "Belli: realidad en carne viva". El comercio, Semanario dominical (Lima) 17 de mayo 1964: 8. No obstante la crítica en general encuentra oscura la poesía de Belli, el autor la considera realista y representante de la situación de su país. Analiza El pie sobre el cuello considerándolo una obra madura y excelente. También en: $E l$ pesapalabras: Carlos Germán Belli ante la crítica. Miguel Angel Zapata, ed. Lima: Tabla de Poesía Actual, 1994. 178-79. 
"Dos poetas, dos ensayos de existencia". La gaceta (México) agosto 1964: 4. Artículo dedicado a Blanca Varela y Belli en quienes encuentra preocupación existencial. Los poemas de Belli, escritos en lenguaje formal, expresan de modo realista las limitaciones del individuo en nuestra sociedad.

"Un poeta y el compromiso que asume." La prensa (Lima) 11 de abril 1958: 12. A pesar de que considera algunos de los poemas en Poemas superficiales y faltos de espontaneidad, el autor señala que este libro incluye también poemas excelentes y creativos que demuestran la capacidad de Belli como poeta.

Santibañez, Roger. "Canciones de Carlos Germán Belli”. La prensa (Lima) 26 de diciembre 1982: 21. Canciones y otros poemas es una repetición de viejas fórmulas usadas ya muchas veces por el poeta. Ahora este talentoso poeta debe enfrentar un nuevo reto, el de transformar su poesía. Esto lo logrará abandonando viejas fórmulas y revitalizando su poesía con un ritmo nuevo.

Schopf, Federico. Reseña de !Oh Hada Cibernética! Anales de la Universidad de Chile octubre-diciembre (1964): 228-31. Estos poemas producen sensaciones diversas en el lector: "Poesía [...] de pura e intencionada imitación, alejada por ello del entusiasmo y la invención en un afán ocultante y que, sin embargo, pálidamente, delicadamente nos habla de la condición del poeta, provocando en nosotros, una vez conocidas las normas, un prolongado y suave estremecimiento".

Sifuentes Oré, Luis. "Carlos Germán Belli: entre el orden y la aventura" La prensa suplemento Perspectiva (Lima) 25 de abril 1982: 17. En la sección "Hojas sin tallo". No ha sido examinado personalmente.

Sologuren, Javier. “Al andar del camino: la poesía del 50: Carlos Germán Belli”. La prensa suplemento dominical La imagen (Lima) 8 de agosto 1976: 22. Belli mezcla lo antiguo y lo moderno; lo distinguido y lo vulgar; graves e irreverentes palabras; lo bucólico y el mundo tecnológico y moderno. Notamos la influencia surrealista, angustia, rebelión y constante exploración del lenguaje.

"Belli selecto: Boda de la pluma y la letra". Debate (Lima) 8.41 (noviembre 1986): 79. "Belli es poeta de una sola, honda y dramática experiencia moral: la injusticia que acosa al hombre tornándolo en un ser condenado a perpetua frustración [...] Belli es a la par antípoda y parangón del creador de Trilce".

"Carlos Germán Belli". Tres poetas, tres obras: Belli, Delgado, Salazar Bondy (claves para su interpretación). Lima: Instituto Raúl Porras Barrenechea, 1969. 7-40. Examina el vocabulario, sintaxis, influencias, temas e ideas recurrentes en la poesía de Belli como: lazos familiares, su hermano, lo bético, el sentimiento de servitud o la opresión de una sociedad dominadora, sus jefes, la vida cotidiana, pobreza, etc. Analiza: "A mi hermano Alfonso", "Sextina del mea culpa" y "Amanuense".

"Carlos Germán Belli: barroquismo y contemporaneidad". Escandalar 4.1 (eneromarzo 1981): 73-74. Examina la obra belliana desde Poemas hasta En alabanza del bolo alimenticio concentrándose en esta última. Un tema común en estos poemas es la injusticia en todos los aspectos de la vida. Utiliza ironía, cierto humor y burla para atacar esta injusticia mezclando lo bucólico, haciendo referencias a la naturaleza, al cosmos y al mundo de la tecnología. Su poesía es un collage de naturaleza personal. Este artículo apareció también en Gravitaciones \& tangencias. Lima: Colmillo Blanco, 1988. 288- 
91 y previamente, con ciertas modificaciones, en Expreso (Lima) 24 de octubre 1979: 10.

"La poesía de Carlos Germán Belli". El pesapalabras: Carlos Germán Belli ante la crítica. Miguel Angel Zapata, ed. Lima: Tabla de Poesía Actual, 1994. 167-75. Análisis panorámico de la obra de CGB desde Poemas.

"Poesía de Carlos Germán Belli" El peruano (Lima) 13 de enero 1995: A-9. Reseña de: La poesía de Carlos Germán Belli: una aproximación. Lima: Universidad de Lima, Facultad de Ciencias Humanas, 1994, de Jorge Cornejo Polar: "Una aproximación que se convertirá en puerta de acceso indispensable para quienes deseen lograr un conocimiento más claro y convincente de la muy valiosa y original obra del poeta de !Oh Hada Cibernética!.

Sucre, Guillermo. "El antiverboy la verba". La máscara, la transparencia: ensayos de poesía hispanoamericana. Caracas, Venezuela: Monte Avila Editores, 1975. 309-24. Entre los poetas estudiados en este capítulo están: Nicanor Parra, Jorge Guillén, Belli, Fernández Moreno, Yurkievich, Dávila Andrade y Rafael José Muñoz. En las páginas 314-15 estudia el lenguaje y estilo de Belli resaltando las diferencias y similitudes entre Belli y Vallejo: "Su poesía no postula un futuro: lo obsesiona la trivialidad y lo sórdido de lo que lo rodea; su ética del sufrimiento se resuelve en una intencional descripción de lo deforme, lo grotesco y aún lo mecánico".

"Poesía crítica: lenguaje y silencio". Revista iberoamericana. 76-77 (julio-diciembre 1971): 575-97. Examina la obra de varios poetas y señala las similitudes y diferencias entre Belli y César Vallejo.

Tamayo Vargas, Augusto. "Boda de la pluma y la letra de Carlos Germán Belli”. Contacto (Lima) 128 (julio-agosto 1986): 3-4. Influenciado en un principio por el surrealismo y el barroco Belli ha creado un estilo propio. Una característica importante es su búsqueda de la forma exacta para el contenido de sus poemas. También en: El pesapalabras: Carlos Germán Belli ante la crítica. Miguel Angel Zapata, ed. Lima: Tabla de Poesía Actual, 1994. 211-14.

Tola de Habich, Fernando. "Carlos Germán Belli: con el pie sobre el cuello". La Prensa, 7 dias del Perú y del mundo(Lima) 26 de mayo 1968: 30-31. Lo más importante para poder entender la obra de Belli es estar conscientes de su realidad, o sea, el hecho de que es un "amanuense". Belli es un empleado y como tal cuenta su condición, angustia, frustraciones, aspiraciones. El hombre y el poeta son uno solamente: el empleado. Sus poemas no expresan ideología moral ni política social o religiosa; a través de ellos encuentra el poeta una avenida para protestar y dar rienda suelta a su angustia y preocupaciones cotidianas.

Urco, Jaime. Reseña de Boda de la pluma y la letra. Kuntur: Perú en la cultura 1 (jul-ago 1986): 55-56. Esta antología comprende poemas escritos en un período de aproximadamente veinticinco años (1958-1983), así podemos apreciar la inspiración del poeta a través del tiempo. Belli combina lenguaje y métrica antiguos evocando así tiempos pasados, pero los temas contemporáneos que emplea y el coloquialismo ocasional nos mantienen en el presente. Básicamente en el universo de Belli hay dos mundos: aquel lleno de holgura en el que todos nuestros deseos son satisfechos y el mundo de frustración, el mundo del hombre común y corriente. 
Vargas Llosa, Mario. "Belli y la rebelión”. El comercio, Suplemento dominical (Lima) 8 de junio 1958: 4-5. Belli es un rebelde pero no un poeta social, ni tampoco está afiliado a un partido político. Presenta la realidad de la vida. Hay unidad interna en sus poemas y a pesar de la angustia y su visión de la realidad hay amor y ternura en su poesía. Esto lo vemos en el poema: "Variaciones para mi hermano Alfonso". Su rebelión no se basa en odio, frivolidad ni estupidez.

"Una poesía para tiempos difíciles". Diario 16, culturas (Madrid) 26 de setiembre 1987: 8. "Su poesía es difícil, melodramática, de un narcisismo negro, impregnada de extraño humor, caústica, cultísima. Está hecha de inconcebibles aleaciones".

Apareció en: Posdata 1.2 (17 de enero 1993): 1-4; El pesapalabras: Carlos Germán Belliante la crítica. Miguel Angel Zapata, ed. Lima: Tablade Poesía Actual, 1994, 201203. Sirvió también como prefacio a Antología crítica pp. i-iii y a: Un giorno l'amore pp. [1-2].

Velázquez, Jaime G. Reseña de Canciones y otros poemas. Vuelta 86 (enero 1984): 34-35. La poesía de Belli es legítima a pesar de que imita formas antiguas.

Vera Ocampo, Raúl. "Poesía arcaica, poesía actual: I". La crónica, Suplemento cultural (Lima) 19 de mayo 1982: 8. El primero de dos artículos en que analiza la evolución, cambios y desarrollo de la poesía de Belli. El autor estudia Poemas, Dentro \& fuera y !Oh Hada Cibernética! En Poemas Belli utiliza importantes elementos innovadores: ritmo y métrica que dan al poema cierta cualidad diferente y un contexto surrealista y barroco. En Dentro \& fuera introduce temas nuevos y en !Oh Hada Cibernética! podemos apreciar un estilo más personal. Señala su visión de la realidad y la forma que ve lo que lo rodea. Circunstancia ésta que será algo muy peculiar en él. En este libro vemos también un marcado parecido a la poesía española de la Edad de Oro e influencia de Quevedo, Garcilaso y particularmente de Góngora.

"Poesía arcaica, poesía actual: II". La crónica, Suplemento cultural (Lima) 26 de mayo 1982: 7. Las formas clásicas empleadas por Belli son también modos de expresar su realidad, al igual que Lope de Vega y Quevedo, Belli hace uso de ironía y sarcasmo. En El pie sobre el cuello podemos apreciar una nota social y sintaxis más elaborada. Por el monte abajo refleja también el uso de temas existenciales. En Sextinas y otros poemas la vida cotidiana se mezcla con experiencias metafísicas y el sufrimiento humano. Este sufrimiento es el resultado de privaciones, diferencias de clase e injusticia. La poesía de Belli refleja la realidad de su época y busca armonía interna y externamente.

Vitale, Ida. "Presentación de Carlos Germán Belli”. Marcha 31 de julio 1970: 33-36. No fue examinado personalmente.

Zapata, Miguel Angel. "Belli o el retrato del edén recuperado". El pesapalabras: Carlos Germán Belli ante la crítica. Miguel Angel Zapata, ed. Lima: Tabla de Poesía Actual, 1994. 263-71. Analiza algunos poemas concentrándose primeramente en el lenguaje e imágenes.

Prólogo, selección y notas. El pesapalabras: Carlos Germán Belliante la crítica. Lima: Ediciones Tabla de Poesía Actual, 1994. 303. Este volumen incluye, además de la introducción del editor, una nota de Alberto Escobar, diecisiete trabajos de diferentes críticos previamente publicados en revistas o libros y cinco textos inéditos de: Christine Legault, Jorge Cornejo Polar, Eduardo Espina, James Higgins y Miguel Angel Zapata. Incluye también una bibliografía activa y pasiva de Belli. 


\section{Bibliografías, Entrevistas y Escritos Varios Sobre Belli}

Aguirre C., Hugo. "Entrevista con Carlos Germán Belli: una especie de precisa oscuridad”. El comercio (Lima) 24 de setiembre, 1989: C-1. Entrevista.

Alvarado Tenorio, Harold. "Conversando con Carlos Germán Belli”. Vanguardia dominical (Bucaramanga, Colombia) (4 época) 494. 13 de setiembre 1981: 6, 8. Entrevista. Incluye seis poemas.

Arcila V., Claudia Antonia. "De viajes y de alquimias" El espectador (magazin dominical) (Bogotá) 525 (6 de mayo 1993): 15-17. Entrevista.

“Asir la forma poética". Moneda (Lima) 16(1989): 59-62. Entrevista. Incluye: “A la enviada del Hada".

"Belli y Corcuera obtienen Premios Nacs. de Poesía". El comercio (Lima) 9 de junio 1964: 12. Belli recibió el Premio Nacional de Poesía 1962, por !Oh Hada Cibernética! y Arturo Corcuera el de 1963, por Poesía.

Borgeson, Paul W., Jr. "Encuentro con Carlos Germán Belli". Línea plural 2 (otoño 1987): 20-23. Entrevista presentada en forma narrativa precedida de un breve estudio crítico sobre la obra de Belli.

BravoE., Carlos. "Carlos Germán Belli: barrocoy socialista”. Puntofinal (Santiagode Chile) 4 de junio 1968: 22. Entrevista.

Cabel. "Belli: creo en todos mis poemas, hasta en los que menos me gustan". Vistazo 3.23 (1973): 32-34. Entrevista.

Calderón, Alfonso. "Carlos Germán Belli: poeta tímido". Ercilla (Santiago de Chile) 1832 (29 de julio al 4 de agosto) 1970: 83, 85. Entrevista.

Calderón Chico, Carlos. "Carlos Germán Beli: soy un vanguardista arrepentido" Crónica del río (Casa de la Cultura, Núcleo del Guayas, Guayaquil) 4-5 (setiembre 1993): 63-67. Entrevista.

Canfield, Martha L. "Una entrevista con Carlos Germán Belli”. Brecha (Montevideo) 22 de agosto 1986: 29. Entrevista.

“Carlos Germán Belli: mi vida gira en torno a la palabra”. La razón 29 de setiembre 1986: [sin paginación]. Entrevista.

“Carlos Germán Belli responde a Trilce". Trilce, (Santiago de Chile) 15-16 (febrero-agosto) 1969: 3-7. Entrevista. Incluye dos poemas.

Castillo, Arnold. "Belli: una larga travesía de sueños y palabras". Congreso (Lima) 19 (marzo-abril 1991): 27-29. Entrevista. (No fue examinada personalmente).

Chirif, Margarita. "Carlos Germán Belli: confesiones de un poeta". La prensa (Lima) 2 de octubre 1983: 20. Entrevista. Incluye dos poemas.

Chirinos Arrieta, Eduardo. "Carlos Germán Belli: un poeta explorador". La prensa, suplemento Perspectiva (Lima) 24 de octubre 1982: 18. Entrevista.

Costa, Marithelmay Adelaida López. “CarlosGermán Belli”. Hispamérica 13.39(1984): 2943. Entrevista. También en: Antología personal páginas 229-45.

E. G. B. "La pequeña muerte de todos los días". El nacional (Caracas) 11 de abril 1976: [sin paginación en la sección Papel interno-poetas latinoamericanos]. Entrevista.

Elmore, Peter y Federico de Cárdenas. "Asir la forma que se va”. El observador (Lima) 22 de diciembre 1982: 4-5. Entrevista. 
Espinoza Suarez, Gabriel. "La torre de marfil portátil: habla el autor de !Oh Hada Cibernética!' Revista Si (del 3 al 9 de julio 1995): 40-45. Entrevista. Incluye también "Raíces y temas" por CGB (nota autobiográfica) 44-45.

Flores, Angel. Spanish American Authors: the Twentieth Century. New York: H.W. Wilson, 1992. 91-92. Ensayo biográfico y bibliografia.

Forgues, Roland. "Carlos Germán Belli: celebrar el orden y la aventura”. Palabra viva. [Lima?]: Studium, 1988. vol. 2 (129-36). Entrevista.

Foster, David William, ed. A Dictionary of Contemporary Latin American Authors. Tempe: Center for Latin American Studies, Arizona State University, 1975. 12-13. Incluye información bio-bibliográfica.

Garavito, Hugo. "Un poeta en la Academia". El comercio, Suplemento dominical (Lima) 25 de abril 1982: 15. Escrito en ocasión de la elección de Belli a la Academia Peruana de la Lengua.

Garganigo, JohnF. “Entrevista con Carlos Germán Belli: Lima 15 de mayo de 1983”. Revista de estudios hispánicos 20.2 (mayo 1986): 83-94. Entrevista.

Gullón, Ricardo, director. Diccionario de la literatura española e hispanoamericana. Madrid: Alianza Editorial, 1993. v. 1. 159. Bio-bibliografía.

Kappatou, Rhegas. "Synenteyche me ton perouviano poiete Karlos Cherman Belli". Proine hevdomada, Mar. 7-13, 1981: E-11. Entrevista. Incluye "La noche". Transcrito del griego.

Kozer, José. “Carlos Germán Belli”. Hombre de mundo 5.6 (junio 1980): 66-69. Entrevista. Llopis-Fuentes, Rogelio. "La postmodernidad en la obra de Carlos Germán Belli". Poetas de enlace (verano 1992): [12]. Entrevista.

Madrid, Antonieta. "Carlos Germán Belli: poeta del absurdo". Imagen (Caracas) 68 (marzo 1970): 3. Entrevista.

Martínez, Cesáreo. "Carlos Germán Belli: mi reto es llegar a ser un escritor renacentista". Desde la vigilia: hablan los escritores y pintores peruanos. [Lima: CONCYTEC], 1989. 179-85. Entrevista.

Martins, Floriano. "O Precioso Mistério da Experiencia Poética: Carlos Germán Belli”. Minas, Gerais Suplemento Literario (Belo Horizonte) 1,134 (18 de novembro 1989): 89. Entrevista.

Martos, Marco. "La alquimia del amor". La crónica, suplemento Hipocampo (Lima) 5 de octubre 1986: 12-13. Entrevista.

Molina, César Antonio. “Carlos Germán Belli: entre la tradición y la transgresión”. Diario 16, culturas (Madrid) 30 de enero 1988: 10. Entrevista.

O’Hara, Edgar. “Conversación con Carlos Germán Belli”. Debate 24: 87-90. Entrevista. Incluye tres poemas: "El guardameta", "Las albóndigas" y "A mi carro".

Orrillo, Winston. "Belli: desde el infierno de lo cotidiano". Oiga (Lima) 4 (setiembre 29, 1967): 22-24. Entrevista.

"Belli en acetato". Expreso (Lima) 6 de octubre 1972: 18. Escrito en ocasión de una grabación de Belli para Ediciones Retablo. El poeta lee cinco poemas: "Poemas", "Abajo las lonjas", "Mis ajos", "Ni de cien mil humanos" y "El guardameta". Esta clase de material es muy valioso tanto en el sentido cultural como en el histórico.

“La poesía, ¿debe ser revolucionaria?” Gente 7.58 (febrero-marzo 1964): 34, 42. Una serie 
de preguntas hechas a: Manuel Scorza, Blanca Varela, Cecilia Bustamante y Belli.

R. V. O. "Con Carlos Germán Belli". La nación (Buenos Aires) 11 de octubre 1970: 3. Entrevista.

Ramírez [Rodríguez], Rómulo. "Belli: el poeta se confiesa". Caretas (Lima) 582 (20 de diciembre 1979): 76-77. Entrevista.

"Carlos Germán Belli: entre la tecnología y la fe". El comercio (Lima) 13 de setiembre 1977: 8. Entrevista.

Rivera, Juan Manuel y Javier Barreiro Cavestany. "Escribir y amar contra viento y marea: entrevista con Carlos Germán Belli”. Caribán 1.3-4 (mayo-diciembre 1985): 2, 25-27. Entrevista. Publicada también en La danza del ratón (Buenos Aires) 7.8 (agosto 1987): 59-68.

Ryan, Bryan, ed. Hispanic Writers: a Selection of Sketches from Contemporary Authors. Detroit: Gale Research, 1991. 61-62. Consiste en información biográfica y bibliografia.

Sefamí, Jacobo. Contemporary Spanish American Poets: a Bibliography of Primary and Secondary Sources. New York: Greenwood Press: 1992. 11-14. Bibliografia.

Sifuentes Oré, Luis. "Entre el orden y la aventura". La prensa, suplemento Perspectiva (Lima) 25 de abril 1982: 17. Entrevista.

Sologuren, Javier. "Belli ocupa lugar propio". El comercio, Suplemento dominical (Lima) 25 de abril 1982: 15. Incluye una parte del discurso de Belli el día en que fue introducido a la Academia Peruana de la Lengua.

Valdés Urrutia, Cecilia. "Intento cruzar la angustia de la vida cotidiana". El mercurio (Santiago de Chile) 29 de julio, 1990: E-4-5. Entrevista.

Verástegui, Enrique. "Belli: la convicción de la palabra”. La crónica (Lima) 5to. domingo de agosto 1975: 21-22. Entrevista.

Zapata, Miguel Angel. "Belli y el reto estilístico de la poesía". Linden lane magazine (Princeton, N.J.) 6.2-3 (Apr-Sept 1987): 3-4. Entrevista. Publicado también en Inti 2627 (1987-1988): 9-27. Incluye veinte poemas: "Asir la forma que se va", "Poema", "Segregación no. 1", "Las fórmulas mágicas", "Algún día el amor”, "!Oh alma mía empedrada!”, "Papá, mamá", “!Oh padres, sabedlo bien!”, "Ha llegado el domingo", "!Cuánta existencia menos!”, “!Oh Hada Cibernética!", “Amanuense”, “Cepo de Lima”, "Fisco", "Mis ajos", "El atarantado", "Sextina de los desiguales", "La cara de mis hijas", "Boda de la pluma y la letra" y "Villanela". 
